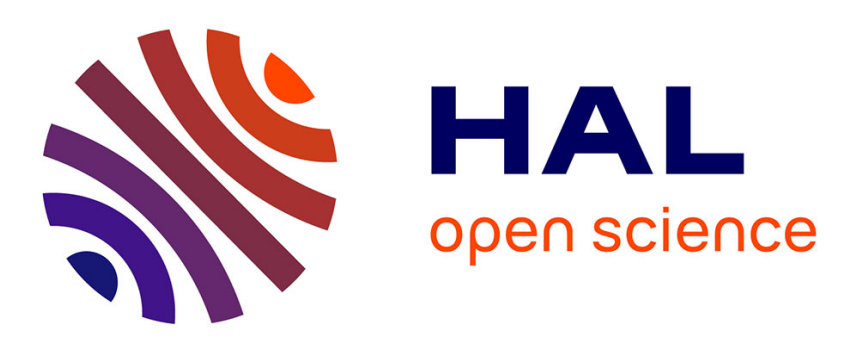

\title{
Further Evidence of Organic Soft Hammer Percussion and Pressure Retouch from Lingjing (Xuchang, Henan, China)
}

Luc Doyon, Hao Li, Zhanyang Li, Hua Wang, Qingpo Zhao

\section{- To cite this version:}

Luc Doyon, Hao Li, Zhanyang Li, Hua Wang, Qingpo Zhao. Further Evidence of Organic Soft Hammer Percussion and Pressure Retouch from Lingjing (Xuchang, Henan, China). Lithic Technology, 2019, 44 (2), pp.100-117. 10.1080/01977261.2019.1589926 . hal-02864070

\section{HAL Id: hal-02864070 https://hal.science/hal-02864070}

Submitted on 29 Sep 2021

HAL is a multi-disciplinary open access archive for the deposit and dissemination of scientific research documents, whether they are published or not. The documents may come from teaching and research institutions in France or abroad, or from public or private research centers.
L'archive ouverte pluridisciplinaire HAL, est destinée au dépôt et à la diffusion de documents scientifiques de niveau recherche, publiés ou non, émanant des établissements d'enseignement et de recherche français ou étrangers, des laboratoires publics ou privés. 


\section{Further Evidence of Organic Soft Hammer Percussion and Pressure Retouch from Lingjing (Xuchang, Henan, China)}

Luc Doyon, Hao Li, ZhanYang Li, Hua Wang \& QingPo Zhao

To cite this article: Luc Doyon, Hao Li, ZhanYang Li, Hua Wang \& QingPo Zhao (2019) Further Evidence of Organic Soft Hammer Percussion and Pressure Retouch from Lingjing (Xuchang, Henan, China), Lithic Technology, 44:2, 100-117

To link to this article: https://doi.org/10.1080/01977261.2019.1589926

Published online: 21 Mar 2019.

Submit your article to this journal $\square$

View Crossmark data $[\pi$ 


\title{
Further Evidence of Organic Soft Hammer Percussion and Pressure Retouch from Lingjing (Xuchang, Henan, China)
}

\author{
Luc Doyon (1) ${ }^{\mathrm{a}, \mathrm{b}}$, Hao $\mathrm{Li}^{\mathrm{c}, \mathrm{d}}$, ZhanYang Li ${ }^{\mathrm{a}, \mathrm{e}}$, Hua Wang ${ }^{\mathrm{a}}$ and QingPo Zhao ${ }^{\mathrm{a}, \mathrm{e}}$

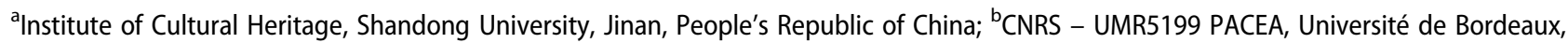 \\ Pessac, France; 'Key Laboratory of Vertebrate Evolution and Human Origins, Chinese Academy of Sciences, Institute of Vertebrate Paleontology \\ and Paleoanthropology, Beijing, People's Republic of China; ${ }^{\mathrm{C} C A S}$ Centre for Excellence in Life and Paleoenvironment, Beijing, People's Republic \\ of China; ${ }^{\mathrm{e} H e n a n}$ Provincial Institute of Cultural Relics and Archaeology, ZhengZhou, People's Republic of China
}

\begin{abstract}
Opinions on the nature and distinctiveness of the Chinese Paleolithic differ between those who assign early Late Pleistocene lithic technologies to some peculiar facies of the Middle Paleolithic, and those who interpret them as reflecting the persistence of essentially Lower Paleolithic traditions. The absence of Levallois debitage and organic soft hammers are often used as arguments, amongst others, in favor of the second hypothesis. Here, we report new supporting data for the use of bone retouchers and pressure flakers in knapping activities. The specimens were found at the Lingjing site, Xuchang County, Henan, in a layer dated between 105 and $125 \mathrm{ka}$. This discovery emphasizes the importance of combining evidence from a variety of aspects of material culture, including anthropogenically modified faunal remains, in order to accurately define Chinese Paleolithic technological traditions.
\end{abstract}

\section{KEYWORDS}

Bone tools; bone retoucher; compressor; early Late Pleistocene; Chinese Middle Paleolithic; archaic hominin

\section{Introduction}

Owing to the ubiquitous presence of lithics in the archaeological record, the elaboration of interpretative framework in Old World archeology heavily relied on the association of lithic assemblages to specific stages of cultural development, i.e. Early or Lower, Middle, and Late or Upper. This tripartite subdivision was thought to correlate with human behavioral and cognitive development, from simpler to more complex (Klein, 2009; Trigger, 1989). Pioneers of Chinese archeology borrowed this schematic subdivision from European and American scholars familiar with the European Paleolithic to classify their findings based on morphological differences in tools and cores (see Bar-Yosef \& Wang, 2012 for a review). The chronological subdivision of the Chinese Paleolithic remained relatively unquestioned throughout the XXth century. However, the review by Gao and Norton (2002) triggered a debate on the existence of a "Middle Paleolithic" in China. Two contrasting views are confronted. There are those who interpret early Late Pleistocene lithic technologies as reflecting the persistence of essentially Lower Paleolithic traditions (Gao, 2013; Gao \& Norton, 2002; Ikawa-Smith, 1978; Li, 2014; Norton \& Jin, 2009; Norton, Gao, \& Feng, 2009; Seong \& Bae, 2016), and those who assign them to some peculiar facies of the Middle Paleolithic (Yee, 2012; Li, 2018; Li, Li, Gao, Kuman, \& Sumner, 2019; Zhang, 1985).

It has been suggested that most Chinese lithic assemblages dated between 300 and 40 ka lack obvious temporal trends and are characterized by the persistence of core-and-flake technology (Gao, 2013; Gao \& Norton, 2002; Ikawa-Smith, 1978; Li, 2014; Norton et al., 2009; Norton \& Jin, 2009; Seong \& Bae, 2016). Poor-quality local raw materials are preferred to exotic lithic sources, the cores show seldom preparation, their reduction most often involves direct hard hammer percussion, block-on-block technique or bipolar percussion, and retouched flakes are rare (Gao, 2013), making these industries hardly distinguishable from Chinese Lower Paleolithic traditions. This pattern contrasts with the one observed in other regions of Eurasia. For instance, the Western Eurasian Middle Paleolithic witnessed the development of the Levallois debitage, the diversification in raw material selection and reduction strategies, the common use of organic soft hammer, and the systematic shaping of stone tools by retouch. The apparent absence of such technological features in large areas of China prior to 40 ka has been interpreted as a consequence of relatively stable environmental conditions coupled with low-intensity resources exploitation, high

CONTACT Luc Doyon — luc.doyon@umontreal.ca 9 Institute of Cultural Heritage, Shandong University, 27 Shanda Nanlu, Jinan 250100, People's Republic of China; ZhanYang Li lizhanyang2621@sina.com E Institute of Cultural Heritage, Shandong University, 27 Shanda Nanlu, Jinan 250100, People's Republic of China

๑ 2019 Informa UK Limited, trading as Taylor \& Francis Group 
group mobility, and the absence of large-scale population replacement events (Gao, 2013). Furthermore, some authors suggested that the persistent preference through time for simple, yet flexible, stone tool technologies likely signals the production of perishable tools made of bamboo (Bar-Yosef \& Wang, 2012; Bar-Yosef, Eren, Yuan, Cohen, \& Li, 2012; Boëda \& Hou, 2011a, 2011 b; Pope, 1988; Schick \& Zhuan, 1993). Consequently, some authors argued the term "Middle Paleolithic" had no meaning in most of East Asia (Gao, 2013; Gao \& Norton, 2002; Ikawa-Smith, 1978; Norton et al., 2009; Norton \& Jin, 2009; Seong \& Bae, 2016), and its use should be restricted to the assemblages comprising Mousterian diagnostics, such as those found in the peripheral regions of northern China, i.e. the Ningxia Autonomous Region (Gao \& Norton, 2002), the Jilin Province (Li, Kuhn, et al., 2018; Wang, Wei, Chen, Tang, \& Wang, 2010), and the Inner Mongolia Region (Chen et al., 2014). However, such interpretative model fails to account for sites such as Panxian Dadong (Otte, Weiwen, Hu, \& Hou, 2017) and Guanyindong Cave (Hu et al., 2019), in southern China, where diagnostic Levallois tools and by-products were discovered in archaeological layers dated between 300 and $80 \mathrm{ka}$.

Over the last decade, the putative stasis of Chinese Paleolithic lithic technologies penecontemporaneous to the European Middle Paleolithic has been questioned. Traditionally, lithic management had been assessed from core reduction strategies, tool typology and the transport of non-local raw material. However, new excavations and re-assessments of known lithic assemblages along distinct lines of evidence are now revealing a previously unforeseen diversity in stone technologies. It now appears that different cultural adaptive systems coexisted in China from the onset of the Late Pleistocene (see Li, 2018 for a review), and likely contributed, alongside the emergence of blade and bladelet technologies (Brantingham, Krivoshapkin, Li, \& Tserendagva, 2001; Lin et al., 2018; Madsen et al., 2001; Madsen et al., 2014; Morgan, Barton, \& Bettinger, 2017), to the highly diversified cultural traditions of the Chinese Late Paleolithic (Qiu, 2009). As Yee (2012) points out, innovative technologies gradually appear in Chinese assemblages between 300 and $40 \mathrm{ka}$, and more work is required to accurately assess the original character of these regional cultural trajectories. The recent discovery of the oldest bone tools known to date in East Asia highlights the importance of identifying such characters from a variety of aspects of past material culture (Doyon, Li, Li, \& d'Errico, 2018), including anthropogenically modified faunal remains, in order to accurately define Chinese Paleolithic technological traditions. These tools consist of bone retouchers and organic soft hammer used in knapping activities (Figure
1). They come from the Lingjing site (Xuchang, Henan), and were found in a layer dated between 105 and $125 \mathrm{ka}$, which has also yielded important archaic hominin remains ( $\mathrm{Li}, \mathrm{Wu}$, et al., 2017; Trinkaus \& Wu, 2017). This discovery supports the latest technological analysis of the associated lithic assemblage found in the same layer, which indicates the shaping and resharpening of stone tools at this locality was produced through freehand hard hammer and organic soft hammer percussion (Li et al., 2019). Li et al. (2019) also hypothesized, based on technological and experimental evidence, the use of pressure flaking for retouching stone implements. In the present paper, we provide further evidence to substantiate these claims. We describe four additional bone retouchers as well as two pressure flakers (French: compresseur) recovered from Lingjing, layer 11.

\section{Bone retoucher versus compressor}

Bone retouchers were signaled in the literature since the end of the XIXth century (see Patou-Mathis \& Schwab, 2002 for a review), and were first interpreted as implements used for the manufacture of stone tools by Henri-Martin (1906). Traces left on bone fragments during their experimental use as retouchers have been widely described (Armand \& Delagnes, 1998; Chase, 1990; Mallye et al., 2012; Mozota Holgueras, 2012a; Patou-Mathis, 2002; Semenov, 1964; Vincent, 1993). Archaeological bone fragments used in knapping activities present single or multiple areas, generally close to the bone ends, bearing modifications that consist of deep, short, closely clustered pits and scores that are sometimes associated to scale removals of cortical lamellae. Apart from a few specimens from African sites (Backwell \& d'Errico, 2005; d'Errico \& Henshilwood, 2007), most of the bone retouchers described in the scientific literature were found in Europe and the Levant. This tool type sporadically appears in the European archaeological record between MIS12 to MIS10, and become a common feature of the Neanderthal toolkits as of MIS9 (e.g. Abrams, 2018; Abrams, Bello, Di Modica, Pirson, \& Bonjean, 2014; Blasco et al., 2013; Costamagno et al., 2018; Daujeard et al., 2014, 2018; Hardy, Pothier Bouchard, \& Doyon, 2014; Jéquier et al., 2015; Jéquier, Livraghi, Romandini, \& Peresani, 2018; Jéquier, Romandini, \& Peresani, 2012; Julien et al., 2015; Kolobova, Markin, \& Chabai, 2016; Moigne et al., 2016; Moncel, Moigne, \& Combier, 2012; Pérez, Hernández, \& Galván, 2019; Rosell, Blasco, Martin-Lerma, Barkai, \& Gopher, 2018; Rosell et al., 2011; Sévêque \& Auguste, 2018; Thun Hohenstein, Bertolini, Channarayapatna, Modolo, \& Peretto, 2018; Toniato, Münzel, Starkovich, \& Conard, 2018; van Kolfschoten, Parfitt, Serangeli, \& Bello, 2015). 
a
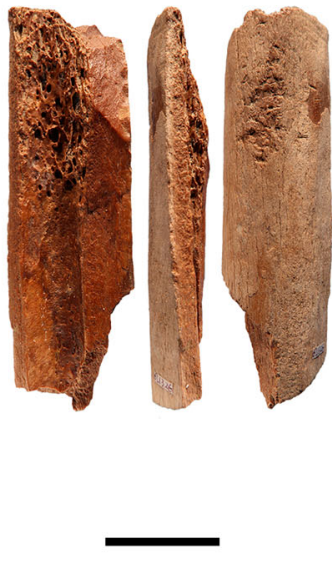

$$
\text { 西 }
$$
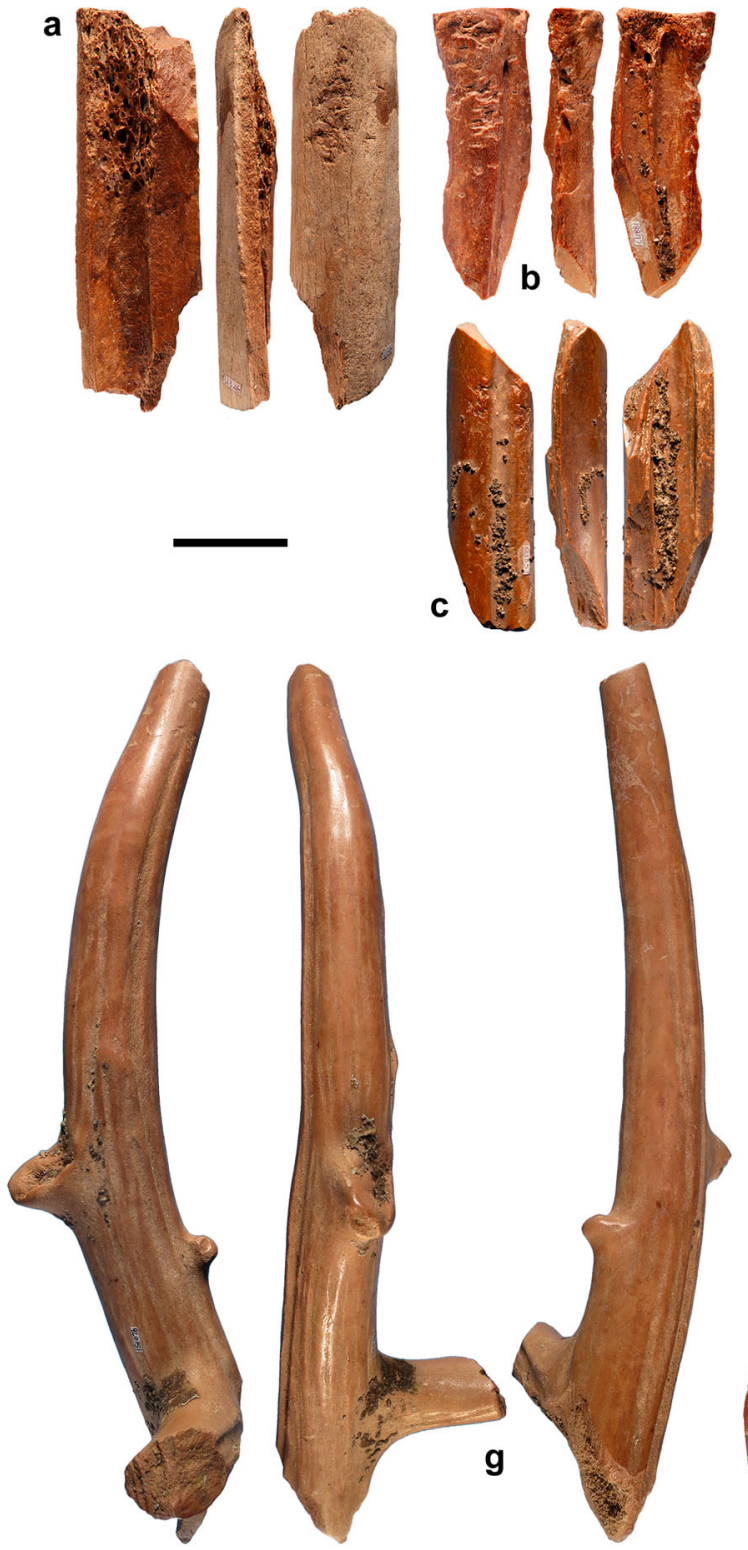

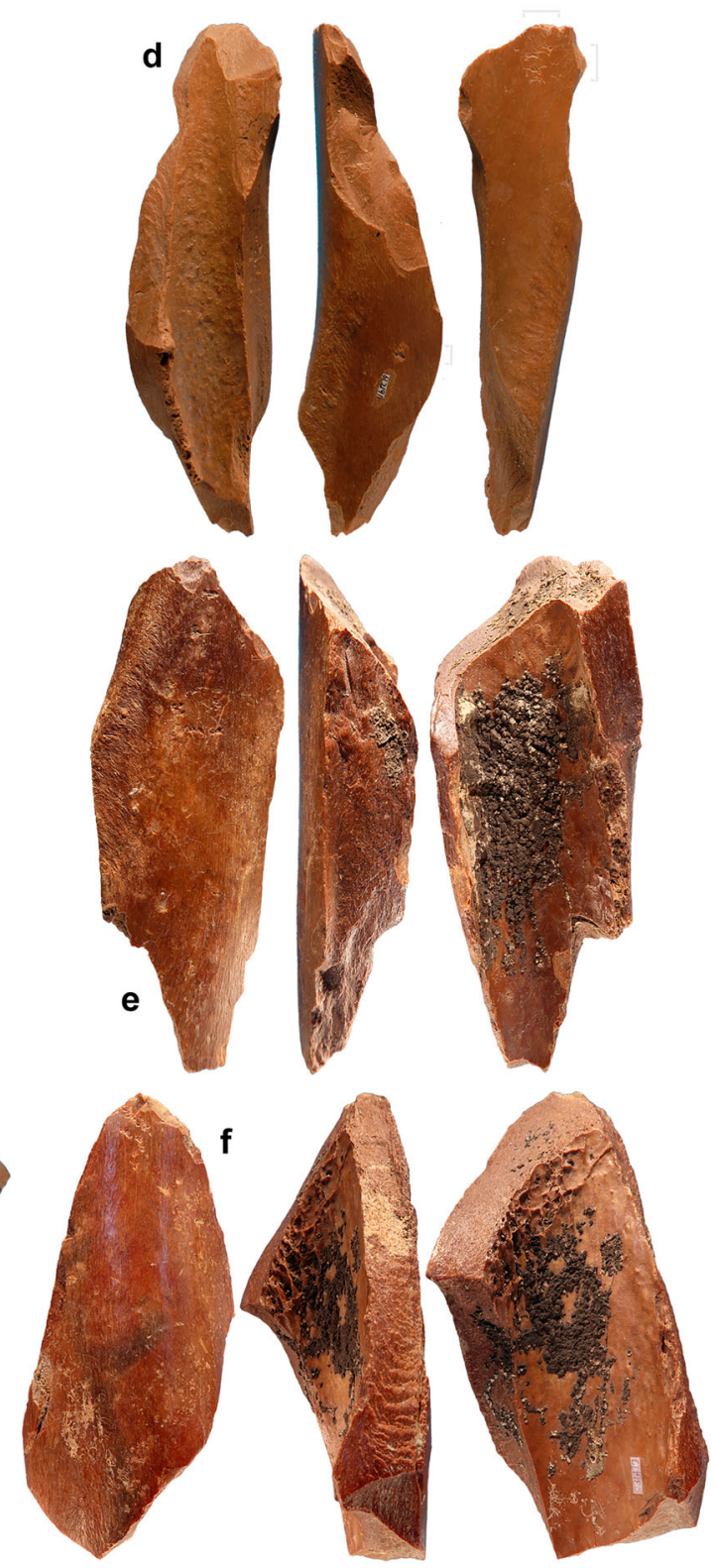

Figure 1. Bone retouchers previously documented from Lingjing; (a-c): curated bone retouchers on weathered bones; (d-f): expedient bone retouchers on fresh bones; (g): antler occasionally used in knapping activities. Modified from Doyon et al., 2018, available via license CC BY 4.0. Scale $=3 \mathrm{~cm}$.

Bone compressors, or pressure flakers, were defined by de Mortillet and de Mortillet (1910) as a bone tool characteristic of the Solutrean period (c. 26-23 ka), used to produce invasive pressure retouch. Rigaud (1977) briefly described the stigmata appearing on the bones fragments he experimentally used for shaping stone tools by pressure retouch, which consist of primary and secondary striations deeply engraved on the bone blanks. Unfortunately, the experimental specimens were not illustrated, which impedes visual comparison. To this day, the distinction between bone retoucher and pressure flakers remain somewhat blurred. This is in part due to the fact that bone fragments could take an active or passive role in pressure retouch (sensu Armand \& Delagnes, 1998). In the former role (Figure 2(a)), the bone implement is placed on the stone implement and the pressure is exerted on the bone towards the stone to remove a flake. Experimental replications and archaeological comparisons (d'Errico, Backwell, \& Wadley, 2012; Nami \& Scheinsohn, 1997) show the traces produced by this motion consist of linear scores perpendicular to the tool's longitudinal axis, sometime combined with striations sub-parallel to this same axis. These striations indicate the secondary 


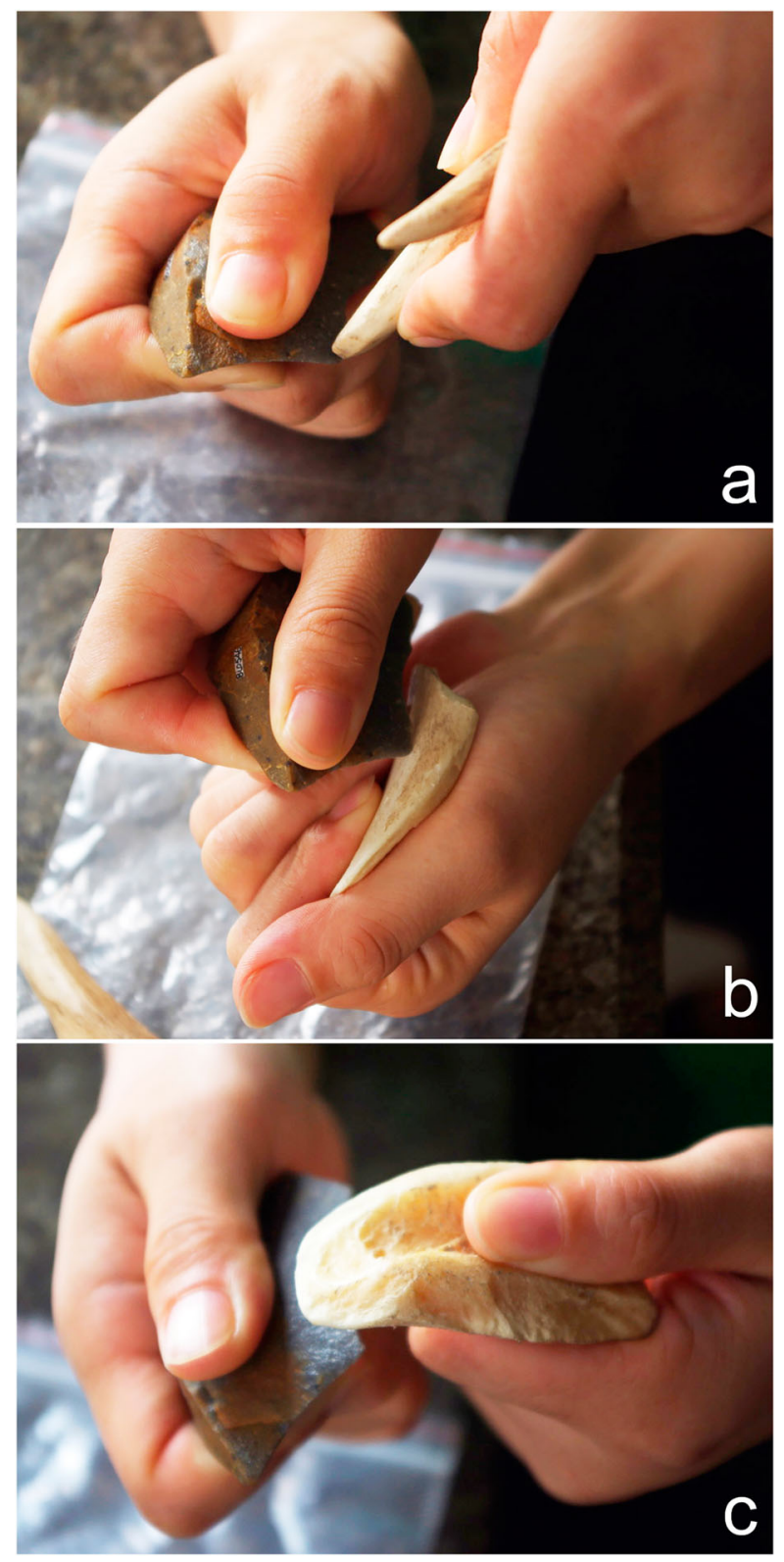

Figure 2. Illustration of the relative position and motion of the lithic and bone tools in (A) pressure flaking with an active bone tool, (B) pressure flaking with a passive bone tool, and (C) retouching by percussion with a bone retoucher.

contact of the pressure flaker on the edge of the stone tool following the detachment of a flake. When the bone compressor takes a passive role in pressure retouch (Figure $2(b)$ ), the stone implement is placed on the bone and the pressure is exerted from the stone tool towards the bone. The resulting stigmata would consist of tightly clustered pits and linear scores (Armand \& Delagnes, 1998; Mozota Holgueras, 2015). Their superimposition and depth increase with the prolonged use of the bone implement. They can sometime be confounded with impact scars resulting from the blow of a bone retoucher on the stone implement
(Figure 2(c)), although, on the latter, they tend to be more dispersed on the used area (Mozota Holgueras, 2015).

\section{Archaeological context}

Lingjing ( $34^{\circ} 04^{\prime} 08.6^{\prime \prime} \mathrm{N}, 113^{\circ} 40^{\prime} 47.5^{\prime \prime} \mathrm{E}$, elev. $117 \mathrm{~m}$ ) is an open-air site located about $120 \mathrm{~km}$ south of the Yellow River in northeast Xuchang County, Henan Province, northern China (Figure 3). This water-lain deposit with a still active water spring was discovered in 1965 when microblades, microcores (Chen, 1983), and faunal remains were found on the surface ( $\mathrm{Li}, \mathrm{Wu}$, et al., 2017). Since 2005, excavations of a $551 \mathrm{~m}^{2}$ area allowed the identification of eleven geological layers, numbered from 1 at the top to 11 at the bottom, within a $9 \mathrm{~m}$ deep sedimentary sequence. The top of the sequence includes layers 1-4, Holocene in age, which yielded material culture spanning from the Shang-Zhou Dynasties to the Neolithic. Layer 5 spans from the Younger Dryas to the LGM and contains microblade technology, microcores, bone artefacts, perforated ostrich eggshells, ochre, faunal remains, and the first evidence of pottery appearing in the region (Henan Provincial Institute of Cultural Relics and Archaeology, China et al., 2018; Li, Kunikita, \& Kato, 2017; Li \& Ma, 2016). Layers 6-9 are sterile. Layers 10 and 11 were deposited during the early Late Pleistocene. Both yielded lithic artefacts and faunal remains (Li, Li, Lotter, \& Kuman, 2018). Two incomplete human skulls were found in layer 11 . They bear a mosaic of morphological features interpreted as indicating both regional continuity and interregional population dynamics (Trinkaus et al., 2017; Li, Wu, et al., 2017).

The faunal assemblage from the early Late Pleistocene layers mainly includes Equus caballus, Equus hemionus, and Bos primigenius remains. The faunal spectrum is complemented with skeletal elements of Megaloceros ordosianus, Cervus elaphus, Coelodonta antiquitatis, Procapra przewalskii, Dicerorhinus mercki, Pachycrocuta cf. sinensis, Palaeoloxodon sp., Viverra cf. zibetha, Ursus sp., Sus lydekkeri, Hydropotes pleistocenica, and Axis shansius (Dong \& Li, 2009; Li \& Dong, 2007). Despite the presence of hyena remains and coprolites at the site ( $\mathrm{Li} \&$ Dong, 2007; Wang, Li, Song, \& Wu, 2015; Wang, Wu, Song, Zhao, \& Li, 2014), this specie likely played a limited role in the accumulation of the faunal assemblage (Zhang, Gao, Zhang, \& Li, 2011). The skeletal element profile of equids and bovids dominated by limb bones $(>60 \%)$, the high frequency of cut-marks $(\sim 34 \%)$, and their location on bone midshafts indicate Lingjing layer 11 was a kill-butchery site (Zhang, Li, Zhang, \& Gao, 2009, 2011, 2012). The grassland-dominated vegetation with a mosaic of scattered and mixed forests (Li \& Dong, 

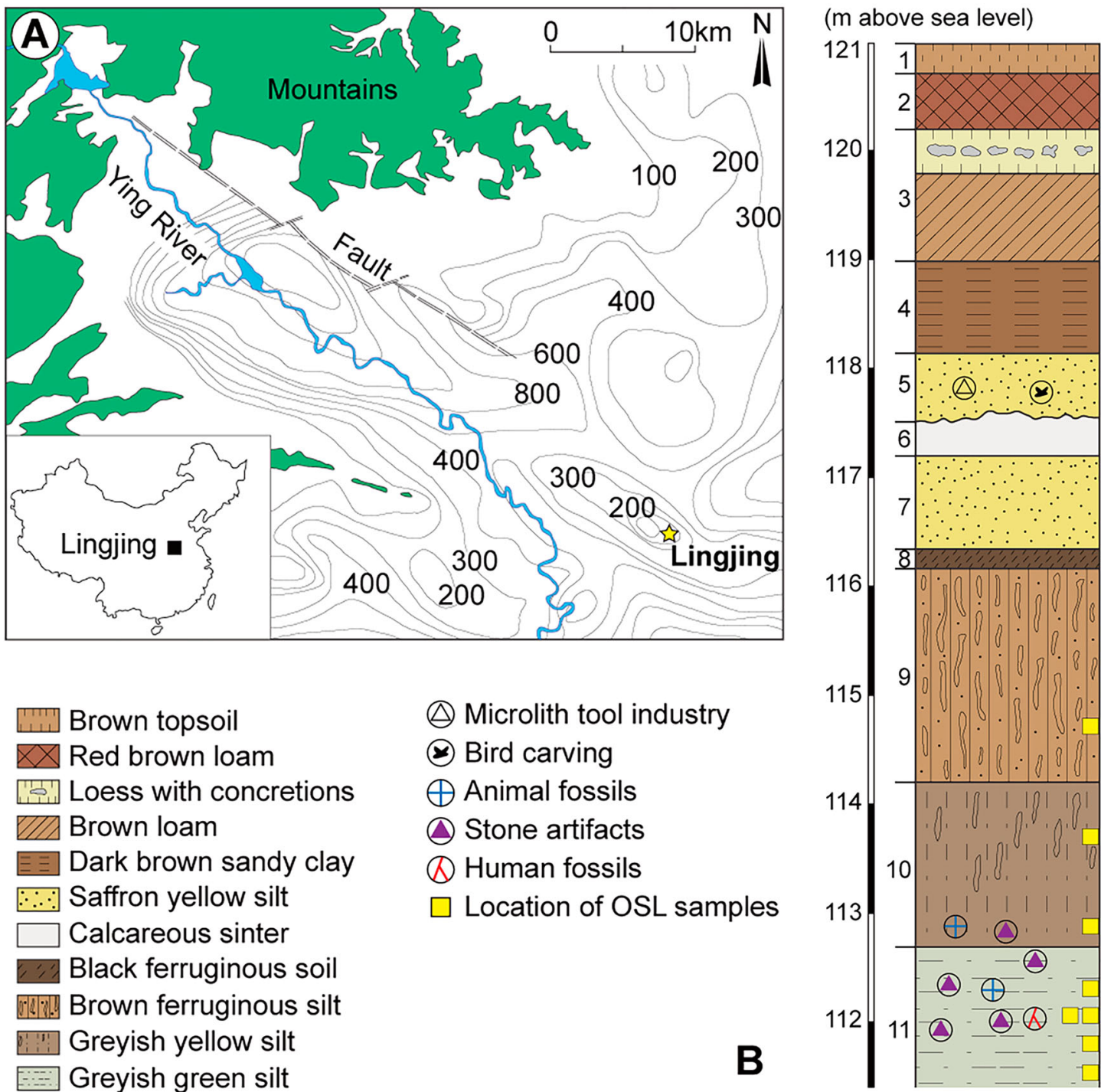

Figure 3. A: Location of Lingjing; B: Stratigraphy indicating the geological and cultural layers. Reproduced after Doyon et al., 2018, available via license CC BY 4.0 .

2007) combined with the presence of an active water spring surely attracted both humans and animals at Lingjing throughout the early Late Pleistocene, as attested by the uninterrupted vertical distribution of faunal and lithic remains in layers 10 and $11(\mathrm{Li}, \mathrm{Li}$, et al., 2018).

The six bone tools reported in the present study come from layer 11. OSL ages indicate the deposition of this layer occurred between 105 and $125 \mathrm{ka}$ (Nian, Zhou, \& Qin, 2009), which corresponds to the early phases of MIS5 (MIS5e to MIS5d). The Lingjing hominins mainly exploited local lithic raw material such as quartz and quartzite. Sandstone, basalt, and chert are also represented in marginal proportions ( $\mathrm{Li}$, $\mathrm{Li}$, et al., 2018). The lithic assemblage includes hard hammers, some of which were recycled into cores (Figure 4), a variety of cores (i.e. multifacial, discoidal, single platform, etc.), flakes, formal tools (i.e. scrapers, notches, denticulates, borers, points, choppers, etc.), and debris (Li et al., 2019). With regard to the shaping and resharpening of stone implements, retouch by hard hammer percussion dominates the assemblage (74.2\%). However, the use organic soft hammer percussion (8.5\%) and pressure flaking (12.0\%) have also been documented ( $\mathrm{Li}$ et al., 2019). Organic soft hammer percussion produces flakes with relatively small size platform, diffused bulb of percussion and a projecting lip (Henry, Haynes, \& Bradley, 1976; Newcomer, 1971; Schick \& Toth, 1993). In comparison, stone implements bearing evidence of pressure retouch present less invasive sub-parallel retouch scars forming a micro-denticulated edge (de la Peña, Wadley, \& Lombard, 2013; Moure, Villa, \& Henshilwood, 2010). 


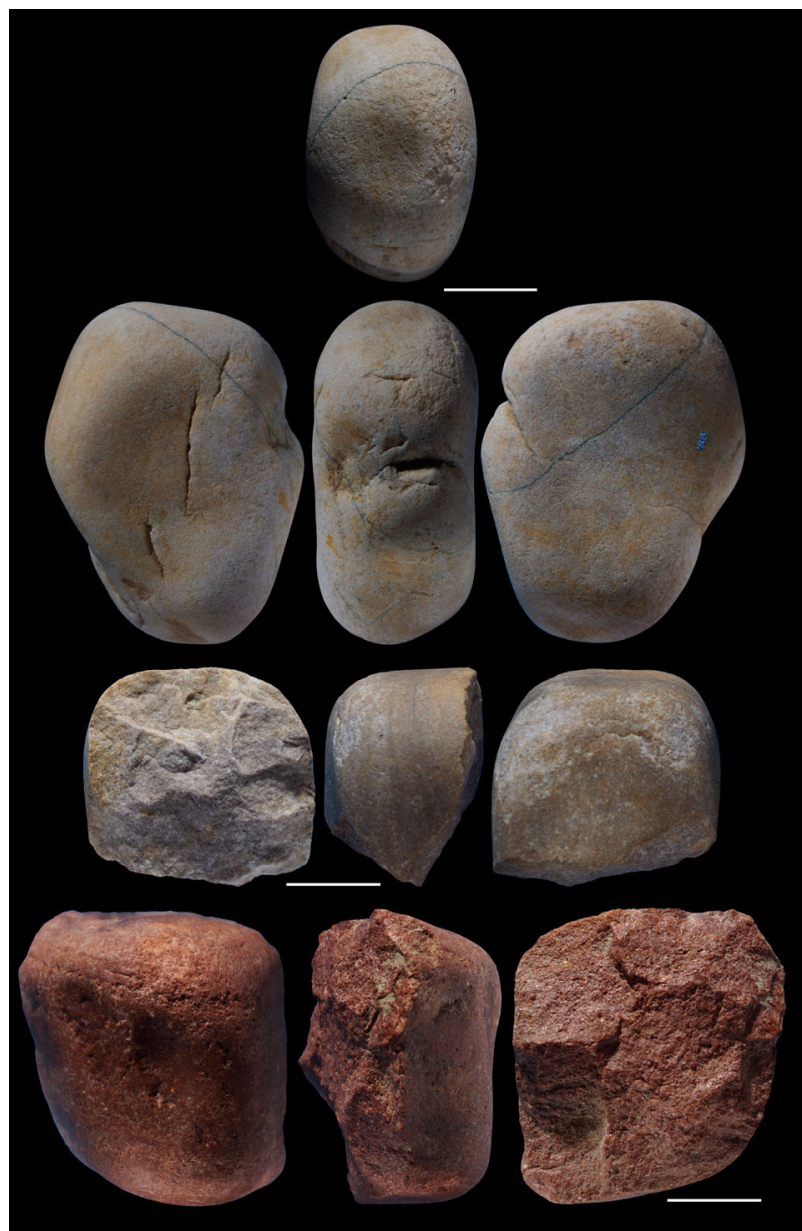

Figure 4. Sample of hard hammers found at Lingjing. Scales = $3 \mathrm{~cm}$.

Together with the identification of use wear on some artefacts (Li, 2007), this evidence suggests knapping activities, and tool manufacture, use, and repair occurred at the site. Finally, layer 11 also yielded two engravings on weathered rib fragments, one of which was covered with ocher (Z. Li et al., in press). This discovery represents the oldest instance of the symbolic use of bone known to date in East Asia.

\section{Materials and methods}

The faunal assemblage from Lingjing amounts to more than 50,000 remains and is curated at the Henan Provincial Institute of Cultural Relics and Archaeology, ZhengZhou, P.R. of China. The artefacts described in the present study were identified during a primary taphonomic assessment of 4,604 faunal remains. This sample includes all the faunal remains recovered in $2017(n=2,236$; layer 10: $n=976$; layer 11: $n=1260$ ), and a comparative sample from layer 11 that was randomly selected amongst the specimens unearthed during the 2005-
2016 excavations $(n=2,368)$. Anthropogenic modifications were distinguished from natural ones following criteria published in the literature (Behrensmeyer, 1978, 1986; Fernández-Jalvo \& Andrews, 2016; Fisher, 1995; Lyman, 1994; Noe-Nygaard, 1989, 1987; Shipman \& Rose, 1983). A particular attention was given to natural and anthropogenic processes that could produce traces similar to those resulting from the use of bone fragments in knapping activities (see below).

Morphometric data, i.e. maximum length, width, and thickness of the bone retouchers and pressure flakers, were collected using a digital caliper. Owing to the lack of characteristic anatomical features, species and anatomical element could not be recorded in most cases. Therefore, the cortical thickness of the bone was used to estimate the animal size class. Surface modifications resulting from the use of bone in knapping activities were identified based on similarities they shared with archaeological and experimental specimens (Daujeard et al., 2014, 2018; Doyon et al., 2018; Hardy et al., 2014; Hutson et al., 2018; Karavanić \& Šokec, 2003; Mallye et al., 2012; Mozota Holgueras, 2008, 2009, 2012a, 2012b, 2015; Patou-Mathis, 2002; Zhang et al., 2018). The number of pits, scores, and scale removals of the primary lamellae were counted in accordance with the terminology proposed by Mallye et al. (2012, p. 1133). "Pits" correspond to depressions on the bone surface produced by its impact on an angular edge of a stone implement. Their form could either be trihedral or ovoid. Among the faunal spectrum identified at the site, both hyenas and bears could have been potential agents for the formation of shallow pits on bone diaphysis. To err on the side of caution, we only counted pits with an angular morphology that were located close to the edge of the bone fragments and found in association with other traces characteristic of knapping activities. "Scores" are more of less deep incisions produced by the impact on a flat edge of a stone tool. Their form can be linear, sinuous, concave or convex, and their internal morphology is either smooth or rough. They differ from other linear marks made by humans or animals in that they show seldom evidence for a directional movement on the bone surface. Furthermore, contrary to root etching, they do not present a corroded branching pattern. "Scale removals" refer to the superficial detachments of the primary bone lamellae. They differ from flaking by weathering and desquamation resulting from the bone being exposed to a highly alkaline environment. Indeed, their occurrence is generally localized and in association with pits and scores, which is indicative of a fairly intensive use of the bone fragment as a retoucher. Finally, the intensive use of a bone retoucher results in the superimposition of traces of impact 
that are grouped into clusters. On archaeological specimens, the maximum length and width of these clusters were recorded. The traces of impact were counted, and the clusters' dimensions were measured on photographs of the specimens with the ImageJ software (Schindelin, Rueden, Hiner, \& Eliceiri, 2015).

We experimentally reproduced the traces of impact on bone surface resulting from passive and active pressure retouch as well as organic soft hammer retouch. We used an antler of Capreolus pygargus bedfordi and limb bone fragments of an ox to retouch flakes detached by hard hammer percussion from cobbles of quartzite similar in shape and size to those from in the lithic assemblage. The number of flaking attempts varied between 25 and 40 for each technique (Figure 2). Wear pattern was monitored after each flaking attempt. The stigmata produced on the bone surface by each technique were compared to the ones recorded on the archaeological specimen in order to test our functional interpretation of the osseous tools. The maximum length, width, and thickness of the retouch flakes detached by each technique were recorded and compared. The archaeological and experimental artefacts were photographed with a Pentax reflex K-r and studied with a Zeiss Smartzoom5 multifocus microscope at magnifications ranging from $10 \mathrm{x}$ to 50x. The quantitative data was processed in the PAST3.1 Software (Hammer, Harper, \& Ryan, 2001).

\section{Results}

\section{Taphonomic modifications}

The faunal assemblage excavated at Lingjing in 2017 is highly fragmented with $85 \%$ of the remains from layer 10 and $70 \%$ of those from layer 11 measuring less than $5 \mathrm{~cm}$ in maximum length (Figure 5(a)). Important differences are observed between the two layers in terms of surface modifications (Figure 5(b)). The faunal elements from layer 10 are heavily affected by weathering (58.6\%), which prevents to fully grasp the type of modifications they underwent prior to their deposition. The other natural modifications include concretion deposits (51.2\%), black stains likely due to manganese dioxide alterations (18.4\%), and root-etching (3.9\%). The remains from layer 11 are less affected by weathering (29.0\%). They often bear concretion deposits (67.9\%) and evidence of root etching (35.8\%). Manganese staining is rather limited (3.5\%). These observations are coherent with the recent conclusions drawn from the analysis of the site formation processes. The deposition of layer 11 likely occurred in a relatively stable, closed and oxygen-poor environment, while the remains from layer 10 were subjected to more frequent rise and fall of the spring water levels ( $\mathrm{Li}$, Li, et al., 2018).

When combining the faunal remains from the 2017 excavation and the comparative sample, surfaces not affected by weathering and bearing little or no concretions show seldom modifications by carnivore $(<1 \%)$. Only rare instances of pits, scores, and etching owing to digestion were observed. Cut marks are the main anthropogenic modification recorded on the assemblage (17.8\%). Other modifications include staining produced by heat (3.9\%), percussion marks possibly for marrow extraction $(2.2 \%)$, and traces of use as bone retoucher $(<1 \%)$. The type of anthropogenic modifications and their relative frequencies are likely underestimated in the Lingjing, layer 11 , assemblage owing to the frequent weathering of, and concretion deposits on, the bone surface. Nonetheless, surface areas not affected by these processes are relatively well preserved and some specimens bear unambiguous traces attesting for their use in a variety of knapping activities.

\section{Technological analysis}

The specimens bearing evidence for their use as retouchers are limb bone fragments from medium to large size mammal presenting fresh fractures $(n=3)$ and a metapodial fragment of a medium size mammal (10L218) with both fresh and weathered fractures (Figures 6-9, Table 1). On one edge of specimen $6 \mathrm{~L} 1505$, a conchoidal fracture on the endosteal aspect is associated with two periosteal impact scars. This combined feature likely resulted from marrow extraction activities. The various taphonomic alterations, i.e. weathering, root etching, concretion deposits, cut marks and heat stain, do not mask the areas where impact traces resulting from knapping activities are present. Each specimen bears a single used area close to the edge (Table 2). The length of the used area varies from 19.4 to $29.9 \mathrm{~mm}$ (average: $24.4 \mathrm{~mm}$; standard deviation: $4.9 \mathrm{~mm}$ ), while their width is comprised between 10.3 and $13.5 \mathrm{~mm}$ (average: $11.8 \mathrm{~mm}$; standard deviation: $1.4 \mathrm{~mm}$ ). The number of impact scars varies between 33 and 140 within each used area, $78.4 \%$ of which are trihedral pits. Both pits and linear scores have a rough internal morphology. The presence of superficial striations tightly clustered between the used area and the distal edge of the tool on 5L587 and 5L611 indicate these two specimens were also used to prepare the margins of the lithic tool before retouching or resharpening it (sensu Jéquier et al., 2018).

Two bone fragments bear evidence for their use as pressure flaker. Specimen 6L1731 is a limb bone fragment of a large size mammal presenting fresh fractures, 


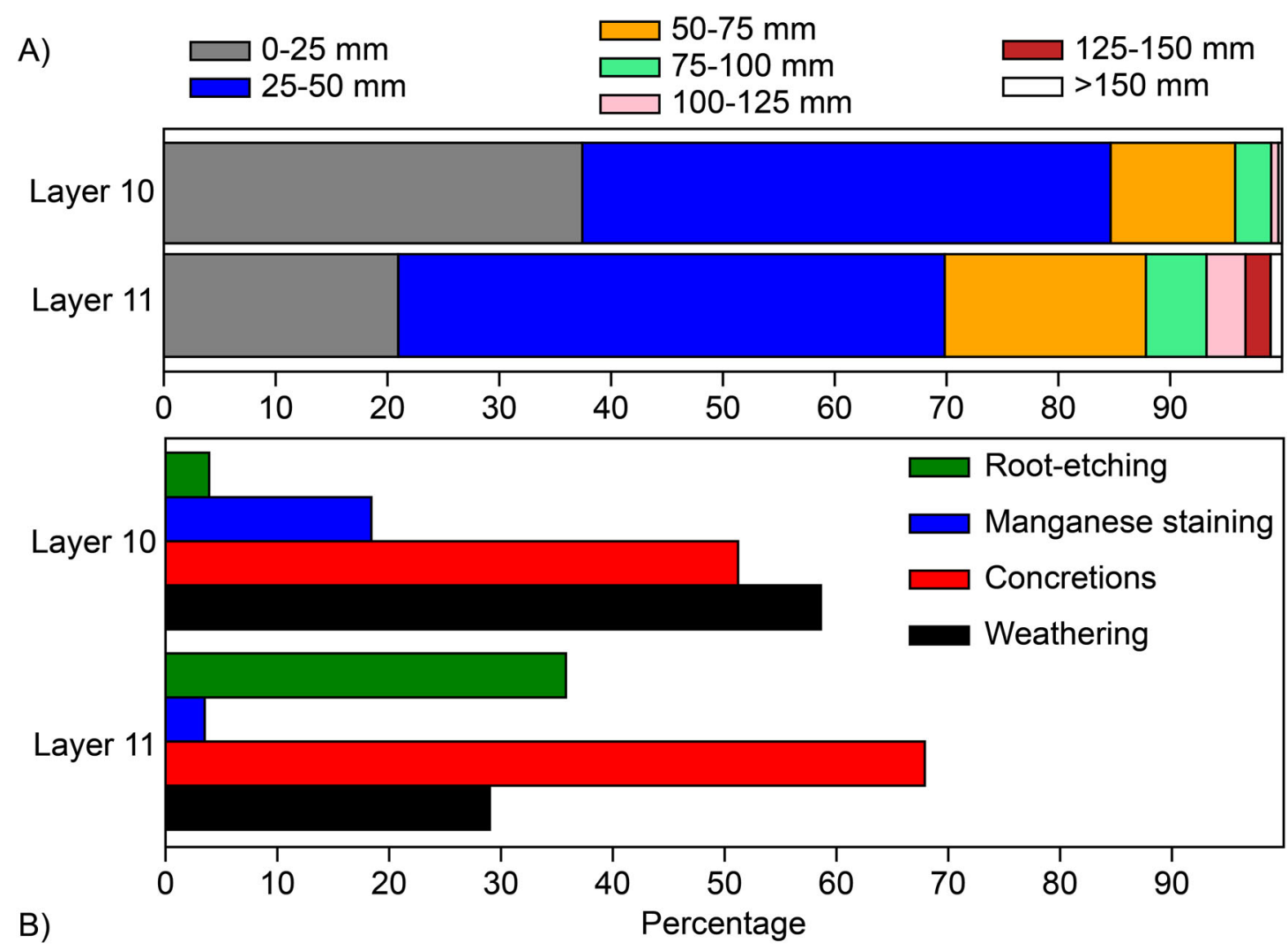

Figure 5. Proportion (\%) of specimens from the faunal assemblage excavated in 2017 (layer 10: $n=976$; layer 11: $n=1260$ ) at Lingjing (A) by maximum length classes, and (B) affected by post-depositional surface alterations.
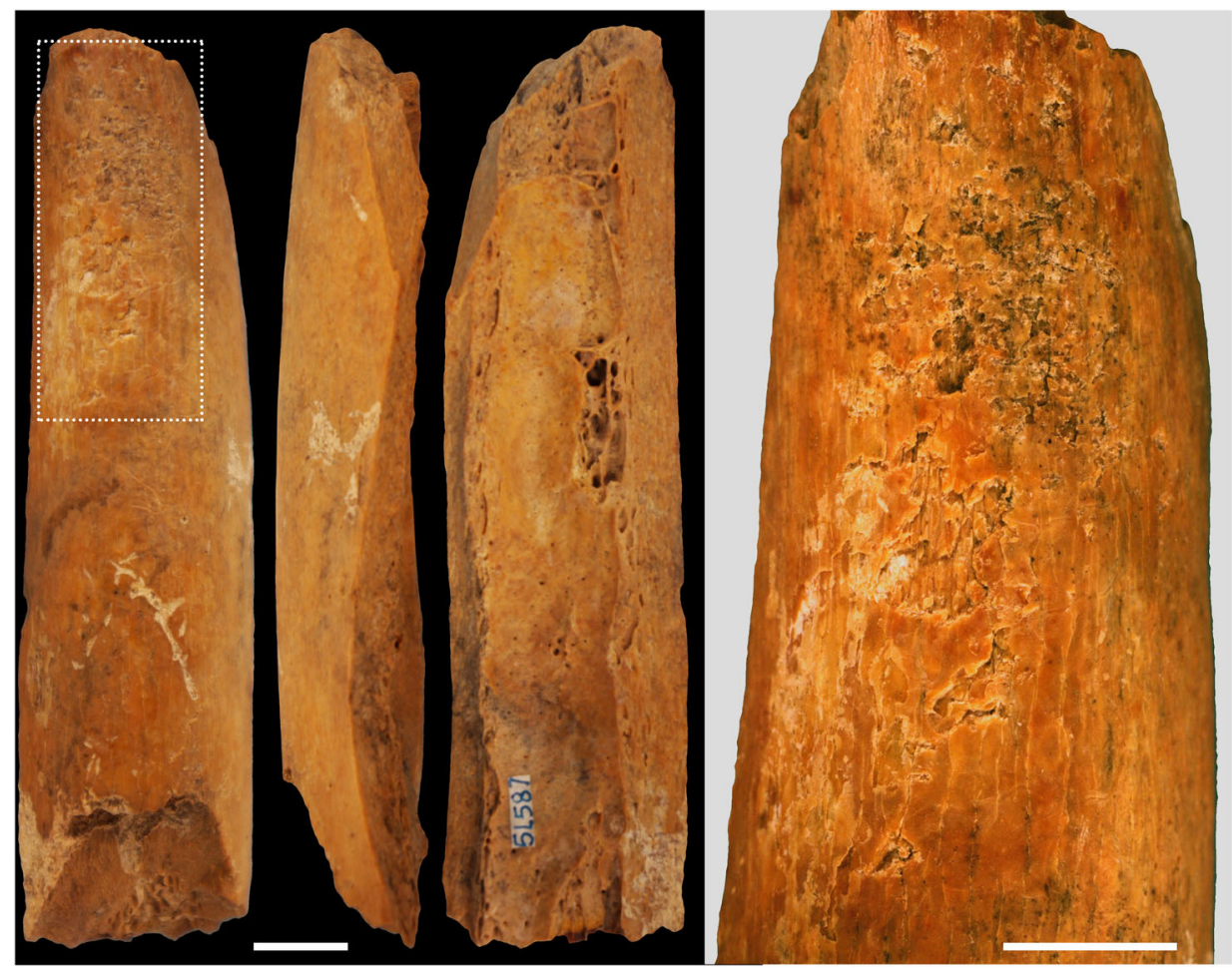

Figure 6. Bone retoucher 5L587 from the Lingjing site. Descriptive, morphometric and technological data available in Tables 1-2. Scales $=1 \mathrm{~cm}$. 

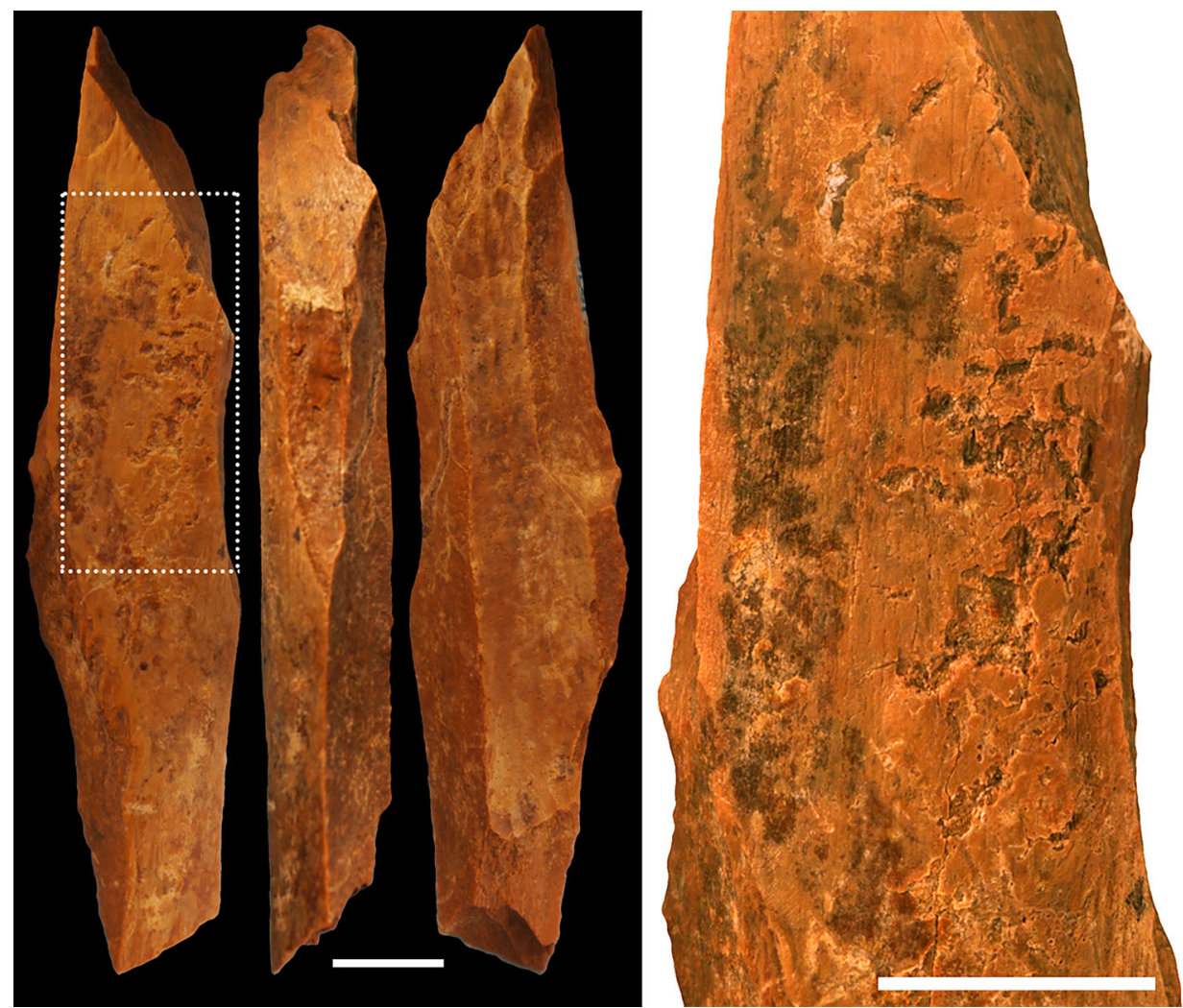

Figure 7. Bone retoucher 5 L611 from the Lingjing site. Descriptive, morphometric and technological data available in Tables 1-2. Scales $=1 \mathrm{~cm}$.

cut marks, and alteration of its periosteal surface by weathering (Figure 10). Close to the distal end, two clusters of tightly superimposed pits and linear scores are visible. The absence of striations and the configuration of the impact scars over the used area suggest this bone fragment served as a passive pressure flaker in at least two occasions. Specimen 17L2889 is a fragment of a cervid antler tine with a recent proximal fracture and three ancient step-fractures adjacent to one another on one aspect of the distal end (Figure 11). Its cortical surface is slightly weathered and bears small concretion deposits. The distal end of the antler tine presents, on the face opposite to the distal step-fractures, ten parallel striations, i.e. six deep and four superficial,

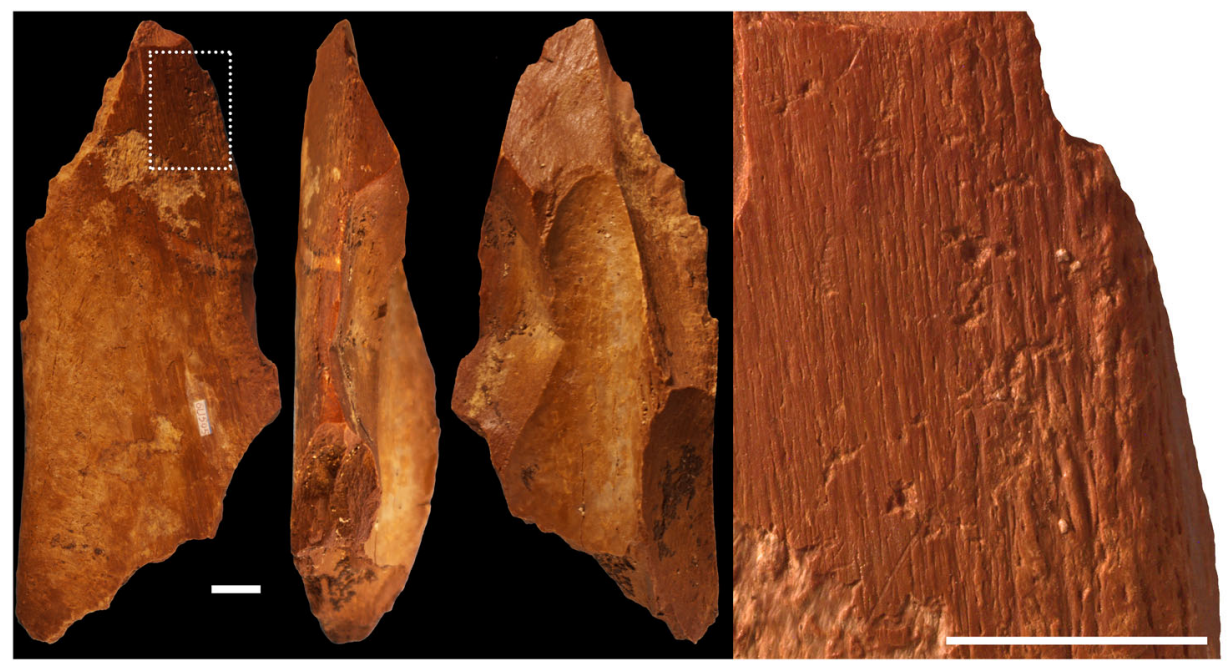

Figure 8. Bone retoucher $6 \mathrm{~L} 1505$ from the Lingjing site. Descriptive, morphometric and technological data available in Tables 1-2. Scales $=1 \mathrm{~cm}$. 

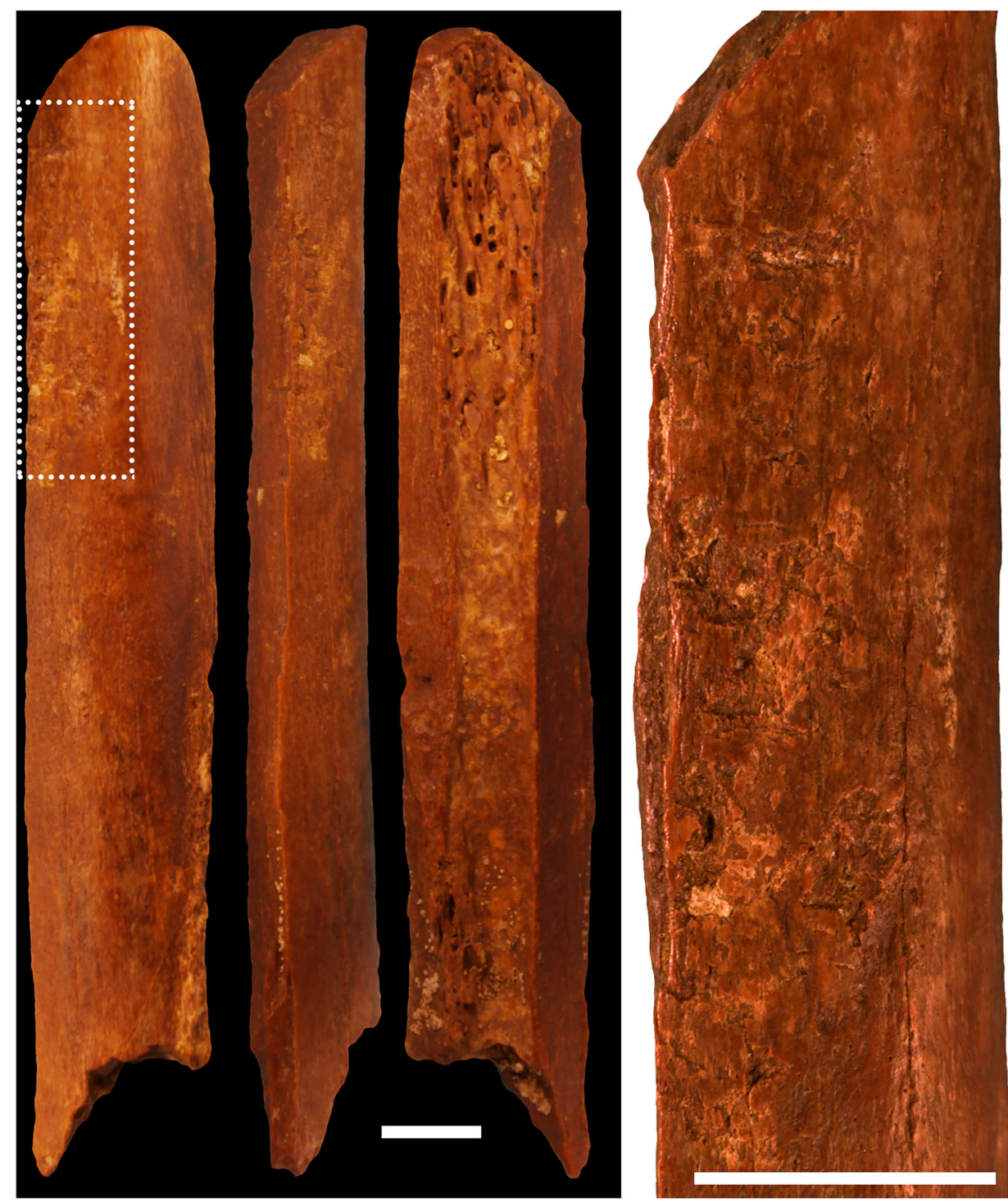

Figure 9. Bone retoucher 10L218 from the Lingjing site. Descriptive, morphometric and technological data available in Tables 12.Scales $=1 \mathrm{~cm}$.

running along the longitudinal axis of the tool. These slightly curved marks resulting from the secondary contact of the pressure flaker on the lithic sharp edge indicate the same motion was successively applied to detach flakes from the stone implement. This evidence suggests this antler tine was used as an active pressure flaker.

\section{Experimental comparison}

During our active pressure retouch experiment, deep striations longitudinal to the tool's axis rapidly developed on the antler tine's surface, i.e. within the first five attempts to detach a flake (Figure 12(a)). Prolonged use of one tine resulted in the formation of a facetted surface covered with similar striations (Figure 12(b)).
The use of a limb bone fragment for passive pressure retouch resulted in the development of a sub-circular used area with superimposed pits and scores. This used area became clearly visible after $15-20$ retouch attempts (Figure 12(c)). Finally, each attempt to retouch quartzite by freehand soft hammer percussion produced a trace of impact, i.e. either a pit or a score, on the bone surface. These traces were spread over the use area (Figure 12(d)).

The retouch flakes detached with each technique differ in a number of ways. When their size is considered, active pressure retouch produced the smallest flakes while freehand soft hammer percussion produced the biggest (Figures 12(e-g), 13). Interestingly, passive pressure flaking produced an impressive quantity of dust particles from crushing the stone flake on the 
Table 1. Descriptive and morphometric data on Lingjing (layer 11) bone retouchers and pressure flakers

\begin{tabular}{|c|c|c|c|c|c|c|c|c|c|c|c|c|}
\hline Catalog $\stackrel{N}{N}$ & Tool type & Animal size & Specie & Element & Lateral fractures & Distal fracture & Proximal fracture & Taphonomy & Length $(\mathrm{mm})$ & Width $(\mathrm{mm})$ & Thickness (mm) & Cortical thickness (mm) \\
\hline $5\llcorner 587$ & Retoucher & M & na & Limb bone & $\mathrm{F}$ & $\mathrm{F}$ & $\mathrm{F}$ & $h, r e$ & 90.9 & 23.3 & 15.9 & 6.6 \\
\hline $5\llcorner 611$ & Retoucher & M & na & Limb bone & $\mathrm{F}$ & $\mathrm{F}$ & $\mathrm{F}$ & re & 78.5 & 18.4 & 12.1 & 8.7 \\
\hline 6L1505 & Retoucher & $\mathrm{L}$ & na & Limb bone & $\mathrm{F}$ & $\mathrm{F}$ & $\mathrm{F}$ & $c, r e, w$ & 117.1 & 50.4 & 26.3 & 13.9 \\
\hline 6L1731 & Passive pressure flaker & $\mathrm{L}$ & na & Limb bone & $\mathrm{F}$ & $\mathrm{F}$ & $\mathrm{F}$ & $\mathrm{cm}, \mathrm{w}$ & 80.7 & 58.1 & 22.3 & 15.3 \\
\hline 10L218 & Retoucher & M & na & Metapodial & W & $\mathrm{F}$ & W & c & 102.9 & 17.8 & 10.7 & 6.8 \\
\hline 17L2889 & Active pressure flaker & M & Cervid sp. & Antler tine & - & na & $\mathrm{R}$ & $c, w$ & 30.4 & 16.1 & 13.0 & 2.7 \\
\hline
\end{tabular}

Animal size: $L=$ large; $M=$ medium; $S=$ Small.

Fractures: $F=$ fresh; $R=$ recent; $W=$ weathered; $n a=$ not applicable

Taphonomy: $\mathrm{c}=$ concretion deposits; $\mathrm{cm}=$ cut marks; $\mathrm{h}=$ heat stain; $\mathrm{re}=$ root etching; $\mathrm{w}=$ weathering

Table 2. Technological data on Lingjing (layer 11) bone retouchers and pressure flakers.

\begin{tabular}{|c|c|c|c|c|c|c|c|c|c|c|}
\hline $\begin{array}{l}\text { Catalog } \\
\stackrel{N}{N} \\
\end{array}$ & Tool type & $\begin{array}{c}\text { Number of } \\
\text { used area }\end{array}$ & $\begin{array}{l}\text { Used area - } \\
\text { Length } \\
(\mathrm{mm})\end{array}$ & $\begin{array}{l}\text { Used area } \\
\text { - Width } \\
(\mathrm{mm})\end{array}$ & $\begin{array}{l}\text { Number } \\
\text { of pits }\end{array}$ & $\begin{array}{c}\text { Number of } \\
\text { scores }\end{array}$ & $\begin{array}{c}\text { Number of } \\
\text { scale } \\
\text { removals }\end{array}$ & $\begin{array}{c}\text { Minimum } \\
\text { impacts/mm2 }\end{array}$ & Striations & $\begin{array}{c}\text { Internal } \\
\text { morphology }\end{array}$ \\
\hline $5\llcorner 587$ & Retoucher & 1 & 27.1 & 13.5 & 115 & 25 & 20 & 0.3827 & css & rough \\
\hline 5L611 & Retoucher & 1 & 21.3 & 10.3 & 56 & 7 & 4 & 0.2872 & css & rough \\
\hline 6L1505 & Retoucher & 1 & 19.4 & 12.2 & 27 & 10 & 3 & 0.1563 & & rough \\
\hline \multirow[t]{2}{*}{ 6L1731 } & $\begin{array}{l}\text { Passive } \\
\text { pressure } \\
\text { flaker }\end{array}$ & 2 & 12.5 & 9.9 & 10 & 12 & 6 & 0.1778 & - & rough \\
\hline & & & 4.7 & 5 & 5 & - & 3 & 0.2128 & - & rough \\
\hline 10L218 & Retoucher & 1 & 29.9 & 11.3 & 23 & 10 & 6 & 0.0977 & - & rough \\
\hline 17L2889 & $\begin{array}{l}\text { Active } \\
\text { pressure } \\
\text { flaker }\end{array}$ & - & - & - & - & - & - & & 10 & rough \\
\hline
\end{tabular}

Striations: css = cluster of superficial striation indicating the preparation of the margins of the lithic tool before retouching or resharpening. 


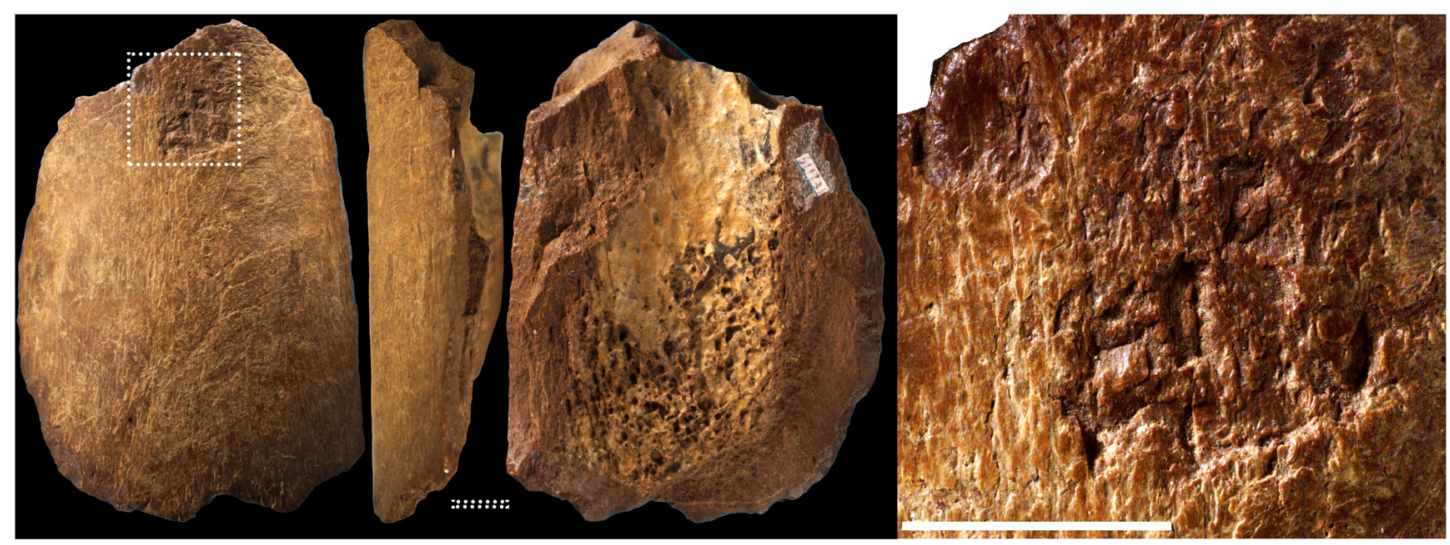

Figure 10. Passive bone pressure flaker $6 \mathrm{~L} 1731$ from the Lingjing site. Descriptive, morphometric and technological data available in Tables $1-2$ Scales $=1 \mathrm{~cm}$.

bone surface. The similar bone surface modifications observed on both the archaeological and the experimental specimens support the functional interpretations drawn from the technological analysis (see above).

\section{Discussion}

The results presented thus far highlight a diversity of know-how in knapping activities at Lingjing. Three distinct behavioral strategies had previously been identified for the use of bone retouchers at this site (Doyon et al., 2018). The first one consists of selecting bone flakes resulting from butchery and carcass processing activities, and utilizing them as such for the expedient retouching and resharpening of stone tools (Figure 1 $(d-f)$ ). The second entails fracturing weathered bones, mainly cervids' metapotials, and shaping them into elongated splinters to be utilized over a long period of time (Figure $1(a-c)$ ). The third strategy refers to the occasional use of antler as soft hammer (Figure 1(g)). The bone retouchers described in the present study fall into the first category. Fresh fractures are present on every specimen, and the tools all bear impact scars clustered in a single area. These bone fragments were likely selected at the site amongst the carcass processing by-products and discarded after an expedient retouching or resharpening event. Although specimen $10 \mathrm{~L} 218$ comes from a metapodial of a medium size mammal, the number of impact scars and their configuration is similar to that observed for knapping area present on expedient retouchers. The two pressure flakers highlight previously undocumented behavioral strategies with regards to the use of bones in knapping activities. When large bone fragments were selected,

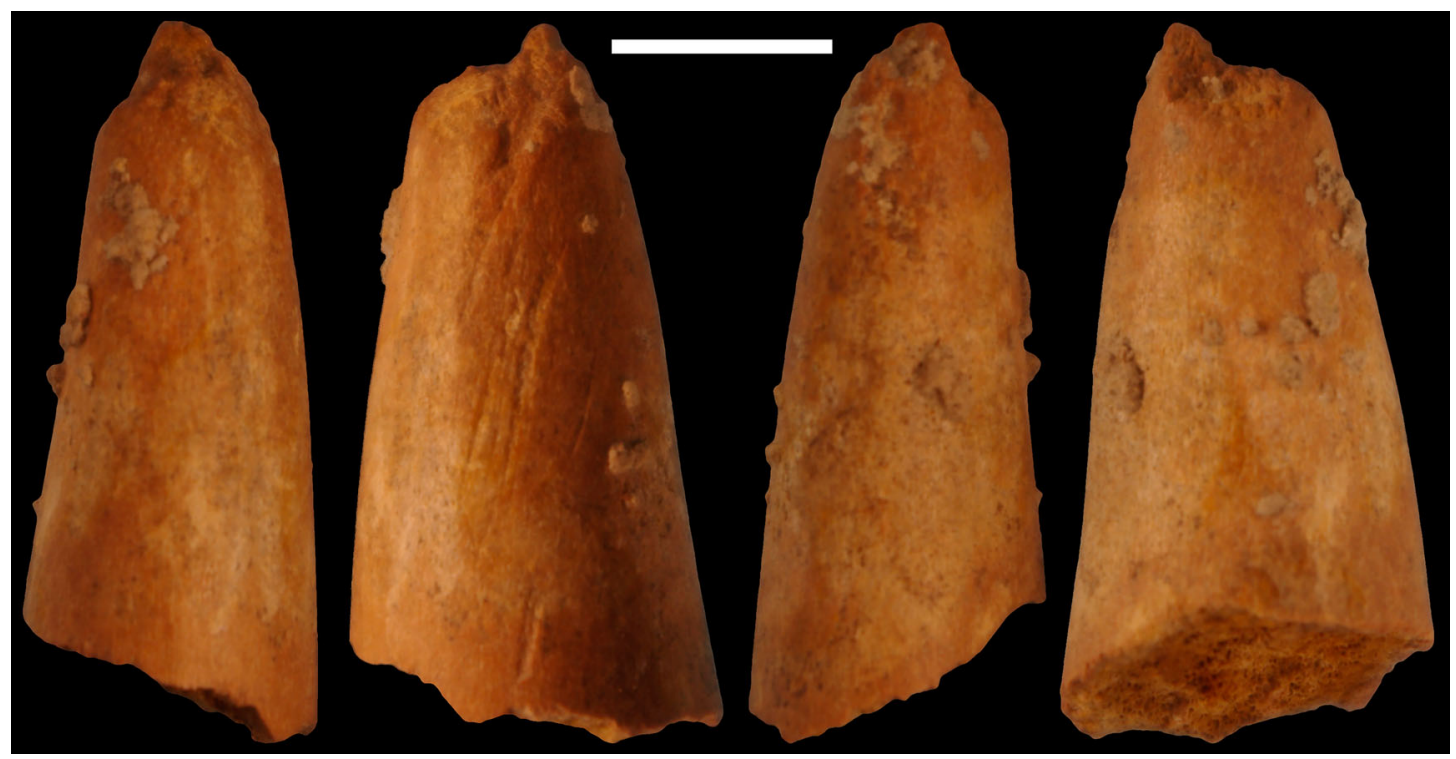

Figure 11. Active bone pressure flaker 17L2889 from the Lingjing site. Descriptive, morphometric and technological data available in Tables $1-2$ Scale $=1 \mathrm{~cm}$. 


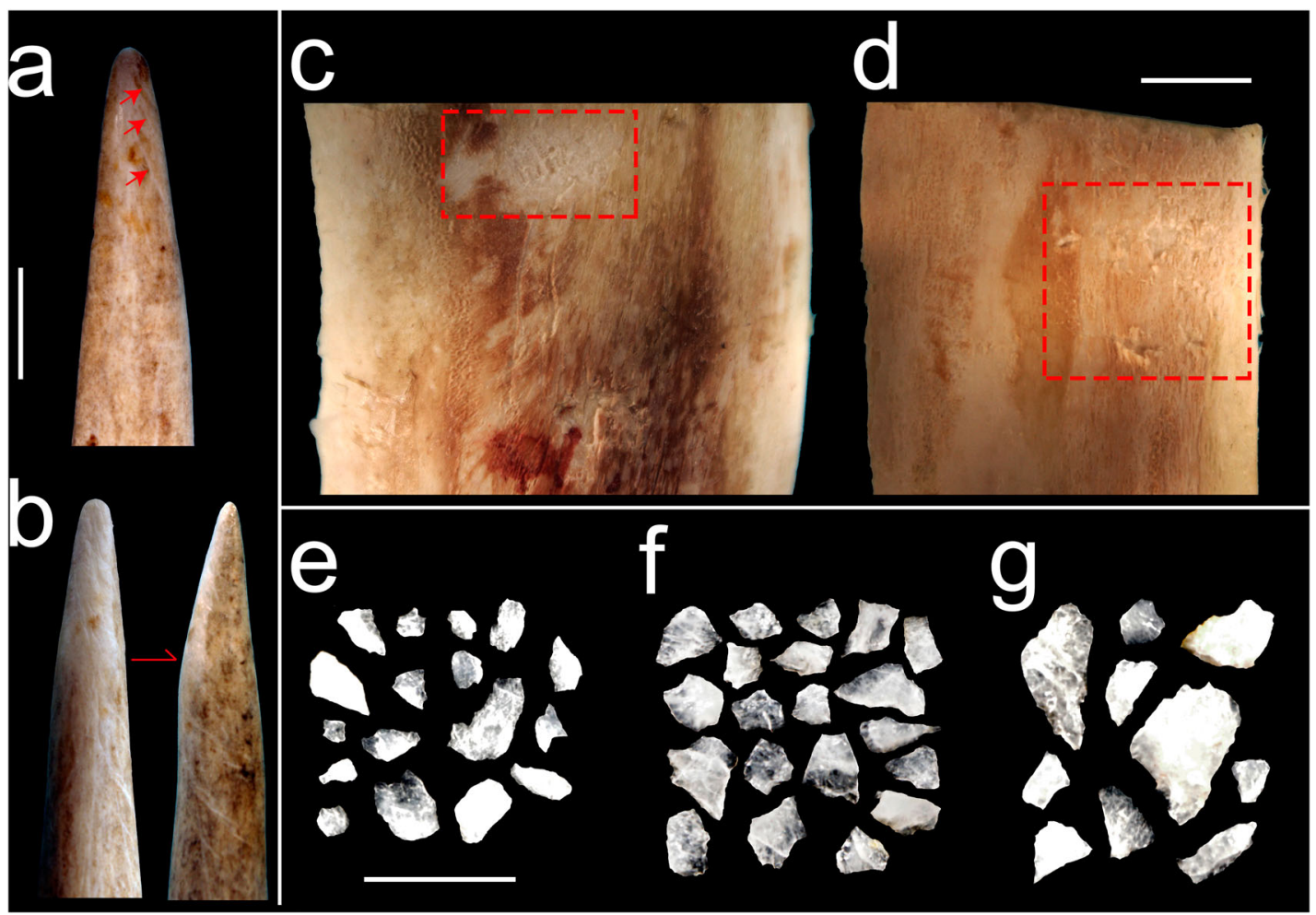

Figure 12. (A) Experimental active pressure flaker with three striations that appeared during the first five flaking attempts; (B) Experimental active pressure flaker with a facetted used area covered with longitudinal striations; (C) Experimental pressure flaker with a subcircular used area covered with superimposed pits and scores; (D) Experimental bone retoucher with pits and scores dispersed over the used area; Quartzite retouch flakes detached by (E) active pressure retouch, (F) passive pressure retouch, and (G) freehand organic soft hammer percussion (see Figure 13 for dimensions). Scales $=1 \mathrm{~cm}$.

they served as a passive tool for pressure retouch. Antler tines, on the other hand, were utilized as an active pressure tool.

Together with the hard hammers found in layer 11, the osseous knapping and retouching tools indicate that Lingjing archaic hominins possessed an extensive knowledge of the mechanical properties of both the organic and mineral resources available in their environment, and knew how to take advantage of these properties in their subsistence activities. The behavioral strategies described above suggest the choice of osseous raw material was not random. Although most bone retouchers fall in the category of expedient tools to satisfy an immediate need, the other specimens suggest the prehistoric artisans sometime intentionally targeted specific skeletal elements to perform particular knapping, retouching and resharpening tasks. More experimental and technological research is required to precisely understand the relationship between the types of raw material selected and the types of knapping activities they were devoted to. Nonetheless, such behavioral consistencies suggest the material culture from Lingjing is likely the expression of a long-lasting tradition whose origin and evolution remain to be eluded.
Future taphonomic and technological investigations of Middle and Late Pleistocene faunal assemblages from East Asia may help identify the origin and evolution of these technological traditions at a regional level.

These results have a broader implication on the nature of cultural adaptations during the early Late Pleistocene, a crucial moment for the dispersals of archaic and modern human populations in East Asia (Armitage et al., 2011; Bae et al., 2014; Cai et al., 2017; Groucutt et al., 2015, 2018; Liu et al., 2010; Petraglia et al., 2007; Shen et al., 2013). The apparent technological stability in East Asian lithic traditions at this time may in fact be illusory. Despite being reminiscent of the Lower Paleolithic simple core-and-flake toolkits when viewed in terms of core reduction strategy, raw material procurement or tool type, these features of Chinese lithic assemblages only represent a limited number of aspects of past cultural adaptations. The temporal trends required to characterize more precisely the technological developments throughout the Chinese Paleolithic may reside elsewhere (see Lin et al., 2018 for a case of differential selection and transportation of local lithic raw material during the MIS3). The discovery of bone retouchers and pressure flakers at Lingjing emphasizes the 


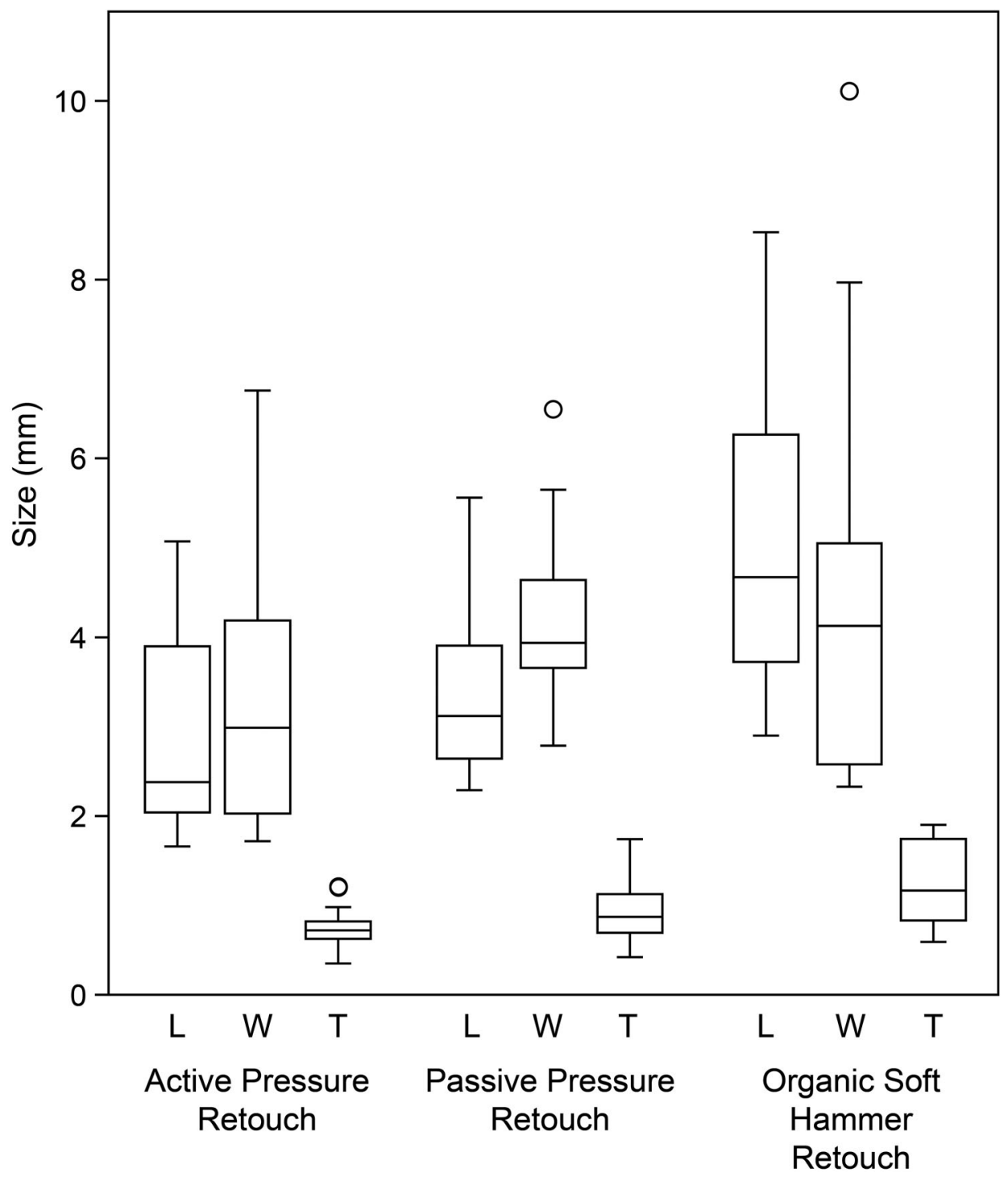

Figure 13. Maximum length $(\mathrm{L})$, width $(\mathrm{W})$ and thickness $(\mathrm{T})$ of the flakes detached by each technique during the experimentation.

importance of including a variety of aspects of material culture, including anthropogenically modified faunal remains, in order to achieve this research objective. To that effect, Lingjing is a peculiar site in many regards. This site yielded a rich lithic assemblage manufactured along a variety of reduction sequences ( $\mathrm{Li}, 2007$; Li et al., 2019), numerous bone tools (Doyon et al., 2018; Li \& Shen, 2010, 2011), and the oldest know example of the use of weathered bones and ochre for non-utilitarian purposes in East Asia (Li et al., in press). This growing body of evidence therefore challenges the idea according to which early Late Pleistocene material culture in China is devoted of innovations. It would seem more appropriate in our view to interpret the cultural remains from Lingjing, layer 11, as one of probably many indigenous Chinese Middle Paleolithic expressions. Although the case of Lingjing does not resolve, in and of itself, the debate on the existence of a "Middle Paleolithic" in East Asia, we argue that behavioral and cognitive abilities of past prehistoric populations may become understandable only through the identification of the original characters of regional cultural trajectories, preferably from a variety of aspect of material culture.

\section{Acknowledgement}

We acknowledge financial support from the Strategic Priority Research Program of the Chinese Academy of Sciences (XDB26000000), the China/Shandong University International Postdoctoral Exchange Program, the Sino-French Xu Guangqi Program (41230RB), the National Natural Science Foundation of China (41630102, 41672020), the Shandong University 111 Project (111-2-09) and the Chinese Academy of Sciences Pioneer Hundred Talents Program. PACEA (UMR5199 CNRS) is a Partner team of the Labex LaScArBx-ANR (ANR-10-LABX-52). The funders had no role in study design, data collection and 
analysis, decision to publish, or preparation of the manuscript. We wish to thank the editor, Grant McGall, as well as two anonymous reviewers for their constructive feedback on an earlier version of this manuscript.

\section{Disclosure statement}

No potential conflict of interest was reported by the authors.

\section{Funding}

We acknowledge financial support from the Strategic Priority Research Program of the Chinese Academy of Sciences [grant number XDB26000000], the China/Shandong University International Postdoctoral Exchange Program, the Sino-French PHC Xu Guangqi Program [grant number 41230RB], the National Natural Science Foundation of China [grant number 41630102, 41672020], the Shandong University 111 Project [grant number 111-2-09] and the Chinese Academy of Sciences Pioneer Hundred Talents Program. PACEA (UMR5199 CNRS) is a Partner team of the Labex LaScArBx-ANR (ANR-10-LABX-52).

\section{Notes on contributors}

Luc Doyon is a Postdoctoral Fellow at the Institute of Cultural Heritage, Shandong University, and a scientific collaborator at the CNRS - UMR5199 PACEA, Université de Bordeaux. He specializes in bone technologies from the European and East Asian Pleistocene.

$\mathrm{Hao} \mathrm{Li}$ is an Associate Professor at the Chinese Academy of Sciences. He specializes in Middle and Late Pleistocene lithic technologies from China and South Africa.

ZhanYang $L i$ is a Professor at the Institute of Cultural Heritage, Shandong University, and a Senior Researcher at the Henan Provincial Institute of Cultural Relics and Archaeology. He directs excavations and research at the Linging site.

Hua Wang is an Associate Professor at the Institute of Cultural Heritage, Shandong University. She specializes in Zooarchaeology and Taphonomy.

QingPo Zhao is a PhD Candidate at Shandong University and a Researcher at the Henan Provincial Institute of Cultural Relics and Archaeology. He studies early Late Pleistocene lithic technologies from the Henan Province.

\section{ORCID}

Luc Doyon (D) http://orcid.org/0000-0001-7163-6186

\section{References}

Abrams, G. (2018). Palaeolithic bone retouchers from Belgium: A preliminary overview of the recent research through historic and recently excavated bone collections. In J. M. Hutson, A. García-Moreno, E. S. Noack, E. Turner, A. Villaluenga, \& S. Gaudzinski-Windheuser (Eds.), The origins of bone tool technologies (pp. 197-213). Mainz: RGZM.

Abrams, G., Bello, S. M., Di Modica, K., Pirson, S., \& Bonjean, D. (2014). When Neanderthals used cave bear (Ursus spelaeus) remains: Bone retouchers from unit 5 of Scladina Cave (Belgium). Quaternary International, 326-327, 274-287.

Armand, D., \& Delagnes, A. (1998). Les retouchoirs en os d'Artenac (couche 6c): perspectives archéozoologiques, taphonomiques et expérimentales [Bone retouchers from Artenac (layer 6c): Archaeozoological, taphonomic and experimental perspectives]. In J.-P. Brugal, L. Meignen, \& M. Patou-Mathis (Eds.), Économie préhistorique: Les comportements de subsistance au Paléolithique. XVIIle Rencontre Internationale d'archéologie et d'histoire d'Antibes (pp. 205214). Antibes: Éditions APDCA.

Armitage, S. J., Jasim, S. A., Marks, A. E., Parker, A. G., Usik, V. I., \& Uerpmann, H.-P. (2011). The southern route "Out of Africa": Evidence for an early expansion of modern humans into Arabia. Science, 331, 453-456.

Backwell, L. R., \& d'Errico, F. (2005). The first use of bone tools: A reappraisal of the evidence from Olduvai Gorge, Tanzania. Palaeontologia Africana, 40, 95-158.

Bae, C. J., Wang, W., Zhao, J., Huang, S., Tian, F., \& Shen, G. (2014). Modern human teeth from Late Pleistocene Luna Cave (Guangxi, China). Quaternary International, 354, 169-183.

Bar-Yosef, O., Eren, M. I., Yuan, J., Cohen, D. J., \& Li, Y. (2012). Were bamboo tools made in prehistoric Southeast Asia? An experimental view from South China. Quaternary International, 269, 9-21.

Bar-Yosef, O., \& Wang, Y. (2012). Paleolithic archaeology in China. Annual Review of Anthropology, 41, 319-335.

Behrensmeyer, A. K. (1978). Taphonomic and ecologic information from bone weathering. Paleobiology, 4, 150-162.

Behrensmeyer, A. K., Gordon, K. D., \& Yanagi, G. T. (1986). Trampling as a cause of bone surface damage and pseudocutmarks. Nature, 319, 768-771.

Blasco, R., Rosell, J., Cuartero, F., Fernández Peris, J., Gopher, A., \& Barkai, R. (2013). Using bones to shape stones: MIS 9 bone retouchers at both edges of the Mediterranean Sea. PLoS ONE, 8, e76780.

Boëda, E., \& Hou, Y. (2011a). Étude du site de Longgupo Synthèse [Study of the Longgupo site - synthesis]. L'Anthropologie, 115, 176-196.

Boëda, E., \& Hou, Y. (2011b). Analyse des artefacts lithiques du site de Longgupo [Analysis of the lithic artefacts from the Longgupo site]. L'Anthropologie, 115, 78-175.

Brantingham, P. J., Krivoshapkin, A. I., Li, J., \& Tserendagva, Y. (2001). The initial Upper Paleolithic of Northeast Asia. Current Anthropology, 42, 735-747.

Cai, Y., Qiang, X., Wang, X., Jin, C., Wang, Y., Zhang, Y., ... An, Z. (2017). The age of human remains and associated fauna from Zhiren Cave in Guangxi, Southern China. Quaternary International, 434, 84-91.

Chase, P. G. (1990). Tool-making tools and Middle Paleolithic behavior. Current Anthropology, 31, 443-447.

Chen, C. (1983). Preliminary exploration of the typology and technology of microcore in China - also of the culture relationship between Northeast Aria and Northwestern North America. Acta Anthropologica Sinica, 2, 331-346.

Chen, H., Hou, Y.-M., Yang, Z., Zhen, Z., Lian, H., \& Liu, Y. (2014). A preliminary study on human behavior and lithic function at the Wulanmulun site, Inner Mongolia, China. Quaternary International, 347, 133-138.

Costamagno, S., Bourguignon, L., Soulier, M.-C., Meignen, L., Beauval, C., Rendu, W.,... Maureille, B. (2018). Bone retouchers and site function in the Quina Mousterian: The case 
of Les Pradelles (Marillac-le-Franc, France). In J. M. Hutson, A. García-Moreno, E. S. Noack, E. Turner, A. Villaluenga, \& S. Gaudzinski-Windheuser (Eds.), The origins of bone tool technologies (pp. 165-195). Mainz: RGZM.

Daujeard, C., Moncel, M.-H., Fiore, I., Tagliacozzo, A., Bindon, P., \& Raynal, J.-P. (2014). Middle Paleolithic bone retouchers in Southeastern France: Variability and functionality. Quaternary International, 326-327, 492-518.

Daujeard, C., Valensi, P., Fiore, I., Moigne, A.-M., Tagliacozzo, A., Moncel, M.-H., ... Raynal, J.-P. (2018). A reappraisal of Lower to Middle Palaeolithic bone retouchers from Southeastern France (MIS 11 to 3). In J. M. Hutson, A. García-Moreno, E. S. Noack, E. Turner, A. Villaluenga, \& S. GaudzinskiWindheuser (Eds.), The origins of bone tool technologies (pp. 93-132). Mainz: RGZM.

de la Peña, P., Wadley, L., \& Lombard, M. (2013). Quartz bifacial points in the Howiesons Poort of Sibudu. South African Archaeological Bulletin, 68, 119-136.

de Mortillet, G., \& de Mortillet, A. (1910). La Préhistoire: Origine et antiquité de l'Homme. Paris: Schleicher frères.

d'Errico, F., Backwell, L. R., \& Wadley, L. (2012). Identifying regional variability in middle stone age bone technology: The case of Sibudu Cave. Journal of Archaeological Science, 39, 2479-2495.

d'Errico, F., \& Henshilwood, C. S. (2007). Additional evidence for bone technology in the Southern African middle stone age. Journal of Human Evolution, 52, 142-163.

Dong, W., \& Li, Z. (2009). New Cervids (Artiodactyla, Mammalia) from the Late Pleistocene of Lingjing site in Henan Province, China. Acta Anthropologica Sinica, 28, 319-326.

Doyon, L., Li, Z., Li, H., \& d'Errico, F. (2018). Discovery of circa 115,000-year-old bone retouchers at Lingjing, Henan, China. PLOS ONE, 13, e0194318.

Fernández-Jalvo, Y., \& Andrews, P. (2016). Atlas of taphonomic identifications. Dordrecht: Springer.

Fisher, J. W. (1995). Bone surface modifications in zooarchaeology. Journal of Archaeological Method and Theory, 2, 7-68.

Gao, X. (2013). Paleolithic cultures in China: Uniqueness and divergence. Current Anthropology, 54(Suppl.), S358-S370.

Gao, X., \& Norton, C. J. (2002). A critique of the Chinese 'Middle Palaeolithic.'. Antiquity, 76, 397-412.

Groucutt, H. S., Grün, R., Zalmout, I. A. S., Drake, N. A., Armitage, S. J., Candy, I., .. Petraglia, M. D. (2018). Homo sapiens in Arabia by 85,000 years ago. Nature Ecology \& Evolution, 2, 800-809.

Groucutt, H. S., Petraglia, M. D., Bailey, G., Scerri, E. M. L., Parton, A., Clark-Balzan, L., ... Scally, A. (2015). Rethinking the dispersal of Homo sapiens out of Africa. Evolutionary Anthropology, 24, 149-164.

Hammer, Ø, Harper, D. A. T., \& Ryan, P. D. (2001). Past: Paleontological statistics software package for education and data analysis. Palaeontologia Electronica, 4, 1-9.

Hardy, M., Pothier Bouchard, G., \& Doyon, L. (2014). Un outil en os à usages multiples dans un contexte moustérien [A multipurpose bone tool from Mousterian context]. Bulletin de la Société préhistorique française, 111, 741-744.

Henri-Martin, L. (1906). Maillets ou enclumes en os provenant de la couche moustérienne de la Quina (Charente) [Bone hammer and anvil from the Mousterian layer of La Quina (Charente)]. Bulletin de la Société préhistorique de France, 3, 155-162.
Henry, D. O., Haynes, C. V., \& Bradley, B. (1976). Quantitative variations in flaked stone debitage. Plains Anthropologist, 21, 5761.

Hu, Y., Marwick, B., Zhang, J. F., Rui, X., Hou, Y. M., \& Li, B. (2019). Late Middle Pleistocene Levallois stone-tool technology in southwest China. Nature, 565, 82-85.

Hutson, J. M., García-Moreno, A., Noack, E. S., Turner, E., Villaluenga, A., \& Gaudzinski-Windheuser, S. (Eds.). (2018). The origins of bone tool technologies. Mainz: RGZM.

Ikawa-Smith, F. (1978). The early Paleolithic tradition of East Asia. The Hague: Mouton.

Jéquier, C., Livraghi, A., Romandini, M., \& Peresani, M. (2018). Same but different: 20,000 years of bone retouchers from Northern Italy. A diachronologic approach from Neanderthals to anatomically modern humans. In J. M. Hutson, A. García-Moreno, E. S. Noack, E. Turner, A. Villaluenga, \& S. Gaudzinski-Windheuser (Eds.), The origins of bone tool technologies (pp. 269-285). Mainz: RGZM.

Jéquier, C., Peresani, M., Romandini, M., Delpiano, D., JoannesBoyau, R., Lembo, G., ... Nicosia, C. (2015). The De Nadale Cave, a single layered Quina Mousterian site in the North of Italy. Quartär, 65, 7-21.

Jéquier, C. A., Romandini, M., \& Peresani, M. (2012). Les retouchoirs en matières dures animales: une comparaison entre Moustérien final et Uluzzien [Bone retouchers: A comparison between the Final Mousterian and the Uluzzian]. Comptes Rendus Palevol, 11, 283-292.

Julien, M.-A., Hardy, B., Stahlschmidt, M. C., Urban, B., Serangeli, J., \& Conard, N. J. (2015). Characterizing the Lower Paleolithic bone industry from Schöningen 12 II: A multi-proxy study. Journal of Human Evolution, 89, 264-286.

Karavanić, I., \& Šokec, T. (2003). The Middle Paleolithic percussion or pressure flaking tools? The comparison of experimental and archaeological material from Croatia. Prilozi Instituta za arheologiju u Zagrebu, 20, 5-14.

Klein, R. G. (2009). The human career (3rd ed.). Chigago, IL: University of Chicago Press.

Kolobova, K. A., Markin, S. V., \& Chabai, V. P. (2016). Bone retouchers in the Middle Paleolithic complexes of Chagyrskaya Cave. Theory and Practice of Archaeological Research, 4, 3539.

Li, F. (2014). Fact or fiction: The Middle Palaeolithic in China. Antiquity, 88, 1303-1309.

$\mathrm{Li}, \mathrm{H}$. (2018). New progresses on the diversity of Chinese lithic technologies in the Early and Middle Palaeolithic. Acta Anthropologica Sinica, 37e, 101-113.

$\mathrm{Li}$, Z. (2007). A primary study on the stone artifacts of Lingjing site excavated in 2005. Acta Anthropologica Sinica, 26, 138154.

Li, Z., \& Dong, W. (2007). Mammalian fauna from the Lingjing Paleolithic site in Xuchang, Henan Province. Acta Anthropologica Sinica, 26, 345-360.

Li, Z., Doyon, L., Hao, L., Wang, Q., Zhang, Z., Zhao, Q., \& d'Errico, F. (in press). Engravings on bone from the archaic hominin site of Lingjing (Xuchang, Henan, China). Antiquity.

Li, F., Kuhn, S. L., Chen, F., Wang, Y., Southon, J., Peng, F., ... Gao, X. (2018). The easternmost Middle Paleolithic (Mousterian) from Jinsitai Cave, North China. Journal of Human Evolution, 114, 76-84.

Li, Z., Kunikita, D., \& Kato, S. (2017). Early pottery from the Lingjing site and the emergence of pottery in northern China. Quaternary International, 441, 49-61. 
Li, H., Li, Z., Gao, X., Kuman, K., \& Sumner, A. (2019). Technological behaviour of the early Late Pleistocene archaic humans at Lingjing (Xuchang, China). Archaeological and Anthropological Sciences. doi:10.1007/ s12520-018-0759-7

Li, H., Li, Z., Lotter, M. G., \& Kuman, K. (2018). Formation processes at the early Late Pleistocene archaic human site of Lingjing, China. Journal of Archaeological Science, 96, 7384.

Li, Z., \& Ma, H. (2016). Techno-typological analysis of the microlithic assemblage at the Xuchang Man site, Lingjing, central China. Quaternary International, 400, 120-129.

Li, Z., \& Shen, C. (2010). Use-wear analysis confirms the use of Palaeolithic bone tools by the Lingjing Xuchang early human. Chinese Science Bulletin, 55, 2282-2289.

Li, Z., \& Shen, C. (2011). Excavation report of the Lingjing Paleolithic site in 2006. Chinese Archaeology, 11, 65-73.

Li, Z., Wu, X., Zhou, L., Liu, W., Gao, X., Nian, X., \& Trinkaus, E. (2017). Late Pleistocene archaic human crania from Xuchang, China. Science, 355, 969-972.

Li, Z., Xing, Y., Mu, J., Wu, X., Kato, S., \& Henan Provincial Institute of Cultural Relics and Archaeology, China, Nara National Institute for Cultural Properties, Japan. (2018). Report of the excavation of microlithic implements on the 5th layer of Lingjing, Xuchang Man site from 2008 to 2013. Huaxia Kaogu / Huaxia Archaeology, 2018, 3-33.

Lin, S. C., Peng, F., Zwyns, N., Guo, J., Wang, H., \& Gao, X. (2018). Detecting patterns of local raw material utilization among informal lithic assemblages at the Late Paleolithic site of Shuidonggou Lovality 2 (China). Archaeological Research in Asia. doi:10.1016/j.ara.2018.11.003

Liu, W., Jina, C., Zhang, Y., Cai, Y., Xing, S., Wu, X., ... Wu, X. (2010). Human remains from Zhirendong, South China, and modern human emergence in East Asia. Proceedings of the National Academy of Sciences, 107, 19201-19206.

Lyman, R. L. (1994). Vertebrate taphonomy. New York, NY: Cambridge University Press.

Madsen, D. B., Jingzen, L., Brantingham, P. J., Xing, G., Elston, R. G., \& Bettinger, R. L. (2001). Dating Shuidonggou and the Upper Palaeolithic blade industry in North China. Antiquity, 75, 706-716.

Madsen, D. B., Oviatt, C. G., Zhu, Y., Brantingham, P. J., Elston, R. G., Chen, F.,... Rhode, D. (2014). The early appearance of Shuidonggou core-and-blade technology in North China: Implications for the spread of anatomically modern humans in northeast Asia? Quaternary International, 347, 21-28.

Mallye, J.-B., Thiébaut, C., Mourre, V., Costamagno, S., Claud, É, \& Weisbecker, P. (2012). The Mousterian bone retouchers of Noisetier Cave: Experimentation and identification of marks. Journal of Archaeological Science, 39, 1131-1142.

Moigne, A.-M., Valensi, P., Auguste, P., García-Solano, J., Tuffreau, A., Lamotte, A., ... Moncel, M.-H. (2016). Bone retouchers from Lower Palaeolithic sites: Terra Amata, Orgnac 3, Cagny-I'Epinette and Cueva del Angel. Quaternary International, 409, 195-212.

Moncel, M.-H., Moigne, A.-M., \& Combier, J. (2012). Towards the Middle Palaeolithic in Western Europe: The case of Orgnac 3 (southeastern France). Journal of Human Evolution, 63, 653666.

Morgan C., Barton L., \& Bettinger R. L. (2017). Looking for behavioral modernity in Pleistocene northwestern China. Archaeological Research in Asia. doi:10.1016/j.ara.2017.07.007
Moure, V., Villa, P., \& Henshilwood, C. S. (2010). Early use of pressure flaking on lithic artifacts at Blombos Cave, South Africa. Science, 330, 659-662.

Mozota Holgueras, M. (2008). A retouching tool/"chisel" (double-use) taphonomic and technological analysis, found at the $C$ level (Mousterian) in Axlor, Dima, Bizkaia. Zephyrus, 61, 217-224.

Mozota Holgueras, M. (2009). Mousterian bone tools from " $D$ " level in Axlor (Dima, Vizcaya): operational sequence analysis. Trabajos de Prehistoria, 66, 28-46.

Mozota Holgueras, M. (2012a). El hueso como material prima: El utillage óseo del final del Musteriense en el sector central del norte de la Península lbérica [Bone as raw material: The Final Mousterian osseous tools from the central region of the North Iberian Peninsula] (Doctoral Dissertation). Universidad de Cantabria, Santander.

Mozota Holgueras, M. (2012b). Two experimental programs to study the bone tools from the Middle Paleolithic hunter-gatherers. In J. Marreiros, N. Bicho, J. F. Gibaja (Eds.), International conference on use-wear analysis "use-wear 2012" (pp. 512520). Cambridge: Cambridge Scholars Publishing.

Mozota Holgueras, M. (2015). Techno-functional analysis of the Mousterian bone retouchers from northern Iberia, and its application to the study of Neanderthal groups. Munibe Antropologia - Arkeologia, 66, 5-21.

Nami, H. G., \& Scheinsohn, V. G. (1997). Use-wear patterns on bone experimental flakers: A preliminary report. In L. Hannus, L. Rossum, \& P. Winham (Eds.), Proceedings of the 1993 bone modification conference, Hot Springs, South Dakota (pp. 256-264). Sioux Falls, SD: Archeology Laboratory, Augustana College.

Newcomer, M. (1971). Some quantitative experiments in handaxe manufacture. World Archaeology, 3, 85-94.

Nian, X. M., Zhou, L. P., \& Qin, J. T. (2009). Comparisons of equivalent dose values obtained with different protocols using a lacustrine sediment sample from Xuchang, China. Radiation Measurements, 44, 512-516.

Noe-Nygaard, N. (1987). Taphonomy in archaeology with special emphasis on man as a biasing factor. Journal of Danish Archaeology, 6, 7-52.

Noe-Nygaard, N. (1989). Man-made trace fossils on bones. Human Evolution, 4, 461-491.

Norton, C. J., Gao, X., \& Feng, X. (2009). The East Asian Middle Paleolithic reexamined. In M. Camps \& P. Chauhan (Eds.), Sourcebook of Paleolithic transitions: Methods, theories, and interpretations (pp. 245-254). New York, NY: Springer.

Norton, C. J., \& Jin, J. J. H. (2009). The evolution of modern human behavior in East Asia: Current perspectives. Evolutionary Anthropology: Issues, News, and Reviews, 18, 247-260.

Otte, M., Weiwen, H., Hu, Y., \& Hou, Y. (2017). Panxian Dadong and the Chinese Levallois. L'Anthropologie, 121, 255-269.

Patou-Mathis, M. (Ed.). (2002). Retouchoirs, Compresseurs, Percuteurs. Os à impressions et éraillures. Fiches de la Commission de Nomenclature sur I'Industrie de l'Os Préhistorique. Cahier $X$ [Retouchers, Compressors, Hammers, Bones with pits and scores. Reference from the commission of the naming convention for prehistoric bone industry. Book X]. Paris: Éditions de la Société préhistorique française.

Patou-Mathis, M., \& Schwab, C. (2002). Fiche générale [Introduction]. In M. Patou-Mathis (Ed.), Retouchoirs, Compresseurs, Percuteurs. Os à Impressions et Éraillures. 
Fiches de La Commission de Nomenclature Sur I'Industrie de I'Os Préhistorique. Cahier X (pp. 11-19). Paris: Éditions de la Société préhistorique française.

Pérez, L., Hernández, C. M., \& Galván, B. (2019). Bone retouchers from the Middle Palaeolithic site of El Salt, Stratigraphic Unit Xa (Alicante, Spain): First data and comparison with the Middle to Upper Pleistocene European record. International Journal of Osteoarchaeology. doi:10.1002/oa.2732

Petraglia, M., Korisettar, R., Boivin, N., Clarkson, C., Ditchfield, P., Jones, S., ... White, K. (2007). Middle Paleolithic assemblages from the Indian subcontinent before and after the Toba super-eruption. Science, 317, 114-116.

Pope, G. G. (1988). Recent advances in far eastern paleoanthropology. Annual Review of Anthropology, 17, 43-77.

Qiu, Z. (2009). The Middle Palaeolithic of China. In R. Wu \& J. W. Olsen (Eds.), Palaeoanthropology and Palaeolithic archaeology in the People's Republic of China (pp. 187-210). Walnut Creek, CA: Left Coast Press.

Rigaud, A. (1977). Analyse typologique et technologique des grattoirs magdaléniens de La Garenne à Saint-Marcel (Indre) [Typological and technological analysis of Magdalenian scrapers fromLa Garenne in Saint-Marcel (Indre)]. Gallia Préhistoire, 20, 1-43.

Rosell, J., Blasco, R., Campeny, G., Díez, J. C., Alcalde, R. A., Menéndez, L., ... Carbonell, E. (2011). Bone as a technological raw material at the Gran Dolina site (Sierra de Atapuerca, Burgos, Spain). Journal of Human Evolution, 61, 125-131.

Rosell, J., Blasco, R., Martin-Lerma, I., Barkai, R., \& Gopher, A. (2018). When discarded bones became important: New bone retouchers from the lower sequence of Qesem Cave, Israel (ca. 300-420 ka). In J. M. Hutson, A. García-Moreno, E. S. Noack, E. Turner, A. Villaluenga, \& S. GaudzinskiWindheuser (Eds.), The origins of bone tool technologies (pp. 33-51). Mainz: RGZM.

Schick, K. D., \& Toth, N. (1993). Making silent stones speak: Human evolution and the Dawn of technology. New York: Simon and Schuster.

Schick, K. D., \& Zhuan, D. (1993). Early Paleolithic of China and Eastern Asia. Evolutionary Anthropology: Issues, News, and Reviews, 2, 22-35.

Schindelin, J., Rueden, C. T., Hiner, M. C., \& Eliceiri, K. W. (2015). The ImageJ ecosystem: An open platform for biomedical image analysis. Molecular Reproduction and Development, $82,518-529$.

Semenov, S. A. (1964). Prehistoric technology. London: Cory, Adams and MacKay.

Seong, C., \& Bae, C. J. (2016). The Eastern Asian 'Middle Palaeolithic' revisited: A view from Korea. Antiquity, 90, 1151-1165.

Sévêque, N., \& Auguste, P. (2018). From West to East: Lower and Middle Palaeolithic bone retouchers. In N. France, I. J. M. Hutson, A. García-Moreno, E. S. Noack, E. Turner, A. Villaluenga, \& S. Gaudzinski-Windheuser (Eds.), The origins of bone tool technologies (pp. 133-164). Mainz: RGZM.

Shen, G., Wu, X., Wang, Q., Tu, H., Feng, Y., \& Zhao, J. (2013). Mass spectrometric $U$-series dating of Huanglong Cave in Hubei Province, central China: Evidence for early presence of modern humans in eastern Asia. Journal of Human Evolution, 65, 162-167.

Shipman, P., \& Rose, J. (1983). Early hominid hunting, butchering, and carcass-processing behaviors: Approaches to the fossil record. Journal of Anthropological Archaeology, 2, 57-98.
Thun Hohenstein, U., Bertolini, M., Channarayapatna, S. Modolo, M., \& Peretto, C. (2018). Bone retouchers from two North Italian Middle Palaeolithic sites: Riparo Tagliente and Grotta della Ghiacciaia, Verona. In J. M. Hutson, A. GarcíaMoreno, E. S. Noack, E. Turner, A. Villaluenga, \& S. Gaudzinski-Windheuser (Eds.), The origins of bone tool technologies (pp. 235-250). Mainz: RGZM.

Toniato, G., Münzel, S. C., Starkovich, B. M., \& Conard, N. J. (2018). Middle and Upper Palaeolithic bone retouchers from the Swabian Jura: Raw materials, curation and use. In J. M. Hutson, A. García-Moreno, E. S. Noack, E. Turner, A. Villaluenga, \& S. Gaudzinski-Windheuser (Eds.), The origins of bone tool technologies (pp. 251-267). Mainz: RGZM.

Trigger, B. G. (1989). A history of archaeological thought. Cambridge: Cambridge University Press.

Trinkaus, E., \& Wu, X. (2017). External auditory exostoses in the Xuchang and Xujiayao human remains: Patterns and implications among Eastern Eurasian Middle and Late Pleistocene crania. PLOS ONE, 12, e0189390.

van Kolfschoten, T., Parfitt, S. A., Serangeli, J., \& Bello, S. M. (2015). Lower Paleolithic bone tools from the 'Spear Horizon' at Schöningen (Germany). Journal of Human Evolution, 89, 226-263.

Vincent, A. (1993). L'outillage osseux au Paléolithique moyen: une nouvelle approche [Middle Palaeolithic bone technology: A new approach] (Doctoral Dissertation). Université de Paris $\mathrm{X}$, Paris.

Wang, W., Li, Z., Song, G., \& Wu, Y. (2015). A study of possible hyaena coprolites from the Lingjing site, Central China. Acta Anthropologica Sinica, 34, 117-125.

Wang, X., Wei, J., Chen, Q., Tang, Z., \& Wang, C. (2010). A preliminary study on the excavation of the Jinsitai cave site. Acta Anthropologica Sinica, 29, 15-32.

Wang, W., Wu, Y., Song, G., Zhao, K., \& Li, Z. (2014). Pollen and fungi spore analysis on Hyaenid coprolite from the Xuchang Man site, Central China. Chinese Science Bulletin, $58,51-56$.

Yee, M. K. (2012). The Middle Palaeolithic in China a review of current interpretations. Antiquity, 86, 619-626.

Zhang, S. (1985). Preliminary investigation of the Middle Palaeolithic in north China. Prehistoric Research, 1, 8-22.

Zhang, S., Doyon, L., Zhang, Y., Gao, X., Chen, F., Guan, Y., \& d'Errico, F. (2018). Innovation in bone technology and artefact types in the late Upper Palaeolithic of China: Insights from Shuidonggou locality 12. Journal of Archaeological Science, 93, 82-93.

Zhang, S., Gao, X., Zhang, Y., \& Li, Z. (2011). Taphonomic analysis of the Lingjing fauna and the first report of a Middle Paleolithic kill-butchery site in North China. Chinese Science Bulletin, 56, 3213-3219.

Zhang, S., Li, Z., Zhang, Y., \& Gao, X. (2009). Mortality profiles of the large herbivores from Lingjing Xuchang Man site, Henan Province and the early emergence of the modern human behaviours in East Asia. Chinese Science Bulletin, 54, 38573863.

Zhang, S., Li, Z., Zhang, Y., \& Gao, X. (2011). Cultural modifications on the animal bones from the Lingjing site. Henan Province. Acta Anthropologica Sinica, 30, 313-326.

Zhang, S., Li, Z., Zhang, Y., \& Gao, X. (2012). Skeletal element distributions of the large herbivores from the Lingjing site, Henan Province, China. Science China Earth Sciences, 55, 246-253. 